\title{
A indignação ferroviária: Envelhecimento e trabalho em Pelotas/RS
}

\author{
Guillermo Stefano Rosa Gómez ${ }^{1}$
}

\section{1 - Introdução: Uma crise indignante}

Neste artigo, delineio o que chamei de “indignação ferroviária”, isto é, a postura dos/as trabalhadores aposentados e suas famílias - residentes na cidade de Pelotas, Rio Grande do Sul, Brasil - perante a crise de sua profissão. Argumento que essa indignação crítica apresenta contornos temporais e imagéticos específicos. Denunciar a crise e a precarização das ferrovias, para os ferroviários, é forma de durar sobre o tempo descontínuo. Aponto, ainda, para a importância da Antropologia da Imagem na fabricação de narrativas sobre processos de memória e da participação do pesquisador/a nas redes de duração dos grupos pesquisados, analisando minha própria experiência de pesquisa e interlocução.

Afim de começar a delinear estas temáticas, retomo a greve dos caminhoneiros ${ }^{2}$ que “parou o Brasil”, em maio de 2018. A categoria exigiu a redução dos preços do óleo diesel, que na época subiram mais de 50\% em apenas 12 meses. Como principais impactos das paralisações e bloqueios das estradas, faltaram alimentos nos supermercados, remédios nas farmácias e, claro, combustíveis para o abastecimento de veículos. As formas de organização e comunicação dos rodoviários pelo aplicativo WhatsApp, trouxeram novos desafios, tanto para a compreensão sociológica dos movimentos trabalhadores como para as negociações com o Estado, que tentava em vão identificar uma "liderança” com a qual estabelecer diálogo.

As pessoas nas redes sociais e as mídias tradicionais e alternativas manifestavam uma pluralidade de opiniões e posições. Com o impacto nacional das paralisações os telejornais trouxeram à pauta discussões sobre a necessidade de multimodalidade ${ }^{3}$ no

\footnotetext{
${ }^{1}$ Doutorando do Programa de Pós-Graduação em Antropologia Social da Universidade Federal do Rio Grande do Sul (UFRGS). Mestre em Antropologia Social pela UFRGS. Bacharel em Ciências Sociais pela Universidade Federal de Pelotas (UFPel).

${ }^{2}$ Ver: https://www.bbc.com/portuguese/brasil-44302137. Acessado em 05/05/2019.

3 "Não se pode afirmar apenas que existe um transporte que é mais caro que outro, pois, o que se deve pensar é numa real logística integradora e um planejamento claro que resolva os gargalos dos países. Não se pode falar apenas em meios de transportes, mas, em sistemas de transportes e de multimodalidade.” (Silva Junior, 2007: 34)
} 
transporte e na logística do país. ${ }^{4}$ Naquele momento, os ferroviários aposentados, com os quais interagi ao longo de minha pesquisa etnográfica (2015-2018), pareciam reagir de diferentes formas. De um lado, estavam contentes com o fato de seus anseios e pautas de longa data, tais como a necessidade de investimentos nas ferrovias, a valorização da categoria e a volta dos trens de passageiros, tinham sido retomados, colocados “na primeira página do jornal.” De outro lado, lamentavam os diagnósticos de irreversibilidade do quadro ferroviário brasileiro, desde uma perspectiva orçamentária.

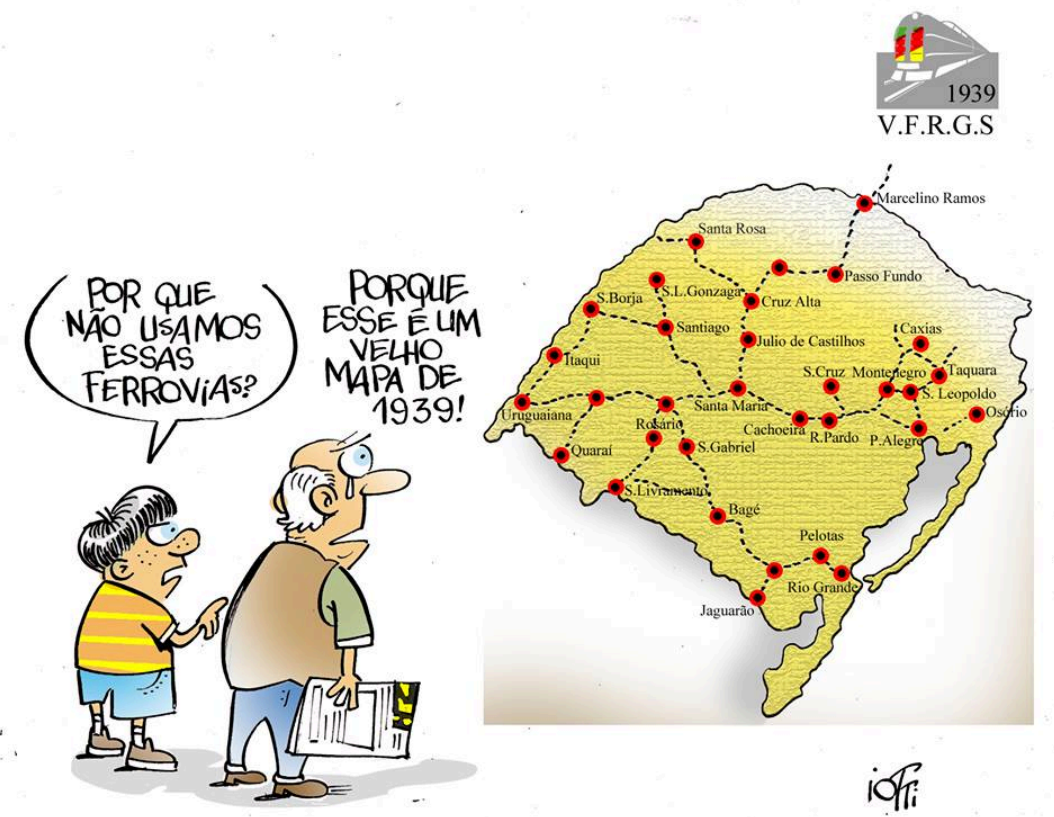

Figura 1: Charge do cartunista Iotti, publicada no jornal Zero Hora, Porto Alegre ${ }^{5}$

A verdade é que o transporte ferroviário brasileiro está em crise há muito tempo e seu processo de desmantelamento vibra na memória dos aposentados. A Rede Ferroviária Federal Sociedade Anônima (RFFSA), empresa federal criada em 1957, unindo quase 18 ferrovias estatais de diferentes regiões (Paradela, 1980: 54), foi a principal administradora desse modelo de transporte. Em seu auge, a RFFSA contou com quase 160 mil trabalhadores (Rapkiewicz \& Eckert, 2015; Amorelli, 2003), um verdadeiro gigante burocrático.

\footnotetext{
${ }^{4} \mathrm{O}$ título da reportagem do Jornal Nacional, um dos veículos televisivos de maior abrangência no Brasil, foi “Greve dos caminhoneiros expõe o quanto o país abandonou as ferrovias". Fonte: http://g1.globo.com/jornal-nacional/noticia/2018/06/greve-dos-caminhoneiros-expoe-o-quanto-o-paisabandonou-ferrovias.html. Acesso em 20/12/2018.

${ }^{5}$ Fonte https://gauchazh.clicrbs.com.br/opiniao/iotti/noticia/2018/06/iotti-ferroviascjhws99ld09zy01pa370958m7.html. Acesso em 20/12/2018.
} 
Naqueles tempos, ser ferroviário era conquistar um status diferenciado entre as classes trabalhadoras, acarretando prestígio econômico, familiar, urbano e, principalmente, como evidenciei em minha pesquisa (Gómez, 2018a), representava a “conquista da estabilidade”. Essa estabilidade tinha seu ônus e bônus pois, era tanto garantia de um projeto "para toda a vida” e da certeza do salário, quanto reflexo de uma política administrativa paternalista e do controle empresarial sobre as vidas dos trabalhadores. A RFFSA aproximava a mão de obra dos locais de trabalho, instituindo na paisagem urbana as “vilas operárias” (Leite Lopes, 1978). As casas, de propriedade da empresa, se somavam a um conjunto de estruturas e políticas da empresa que borravam os limites entre trabalho e não-trabalho. As festas coletivas, os campeonatos de futebol, o atendimento de saúde, a cooperativa de consumo, a educação dos filhos por meio de escolas ferroviárias ou escolas técnicas, a previdência própria, eram relacionados diretamente um “modo de vida” ferroviário e com a RFFSA, integrando colegas de trabalho que eram, também, vizinhos, parentes, amigos.

Como já evidente em diferentes estudos de extrema relevância no campo da Antropologia do Trabalho (Cf. Leite Lopes, 1978; Eckert, 2012; Cioccari, 2015) não há como falar, nessas comunidades de trabalho, de separação estrita entre trabalho e lazer. Se estendem ao mundo do "não-trabalho" os significantes da identidade profissional. Nesse contexto, “ser ferroviário” não era apenas uma designação, mas uma afirmação com orgulho, um pertencimento, uma herança geracional, seja vinda de "sangue” ou conquistada “por acaso” (Gómez, 2018c).

Apesar do prestígio da profissão ferroviária e do fato do setor ter desempenhado papel central nos projetos de desenvolvimento nacionais (Simões, 2004), a opção brasileira inclinou-se pelo transporte rodoviário, em detrimento das ferrovias. Desde o governo de Getúlio Vargas, em 1930, os investimentos nas rodovias foram significativos. O caminhão teve a capacidade de “integrar o território nacional”, por ser “rebelde ao planejamento”, "basta abrir uma clareira e lá vai ele de porta em porta, percorrendo os lugares mais difíceis, nos quais sequer passa uma ferrovia” (Silveira, 2003: 108). De acordo com Silveira: "Enquanto a rodoviarização tomava impulso, o governo federal tratava de encampar as ferrovias, investindo para impedir o modal ferroviário de entrar em um profundo sucateamento” (Silveira, 2003: 116). Já da década de 1950, a própria criação da RFFSA foi parte de uma política que era tentativa de recuperação do setor ferroviário em degradação. O triunfo da rodovia foi o da cidade 
modernista (Holston, 1993), do automóvel (Lefebvre, 1999) e das políticas internacionais de combustíveis derivados do petróleo.

As ferrovias tiverem um agonizante ${ }^{6}$ processo de queda, que culminou com a desestatização da Rede Ferroviária, ao longo da década de 1990. A primeira malha foi privatizada em 1996 e a última em 1999 (Nunes, 2003: 3), tendo como financiador e facilitador o Banco Mundial. A RFFSA foi fragmentada em diferentes concessões privadas, resultando em demissões, aposentadorias precárias ou prematuras, terceirização do trabalho, abandono e fechamento de estações, oficinas e prédios ferroviários, remoção de trilhos e extinção de trechos.

Instigado a conhecer de que maneira a crise ferroviária era vivida e narrada por sua população trabalhadora, me debrucei sobre essa problemática entre os anos de 2015 e 2018 em que fiz trabalho de campo etnográfico na cidade de Pelotas. Os aposentados, de faixa etária média de 60 aos 80 anos e majoritariamente homens, constituíram o principal universo de interlocução, fazendo convergir as temáticas da crise, do envelhecimento e da aposentadoria como diferentes matizes das experiências de descontinuidade com o trabalho.

Na graduação tive as primeiras aproximações com a temática, sob a orientação de Claudia Turra Magni no âmbito do Laboratório de Ensino, Pesquisa e Produção em Antropologia da Imagem e do Som (LEPPAIS) e com maior fôlego e profundidade durante o mestrado em Antropologia Social na Universidade Federal do Rio Grande do Sul (2016-2018), sob orientação de Cornelia Eckert, integrando o Núcleo de Antropologia Visual (Navisual/PPGAS/UFRGS). A experiência de aprendizado no mestrado também significou minha filiação à Etnografia da Duração (Rocha \& Eckert, 2013), isto é, a uma comunidade interpretativa dos estudos da memória coletiva, focada na função imaginativa dos habitantes das cidades. Trata-se, portanto, de um estudo de Antropologia Urbana, desde suas bases clássicas do pensamento brasileiro (Oliven, 1985; Velho, 1981), problematizando a escala de cidade não metropolitana, na qual se realizou a investigação: a cidade média de Pelotas, no Sul do Brasil.

Pelotas se tornou importante para a economia do estado do Rio Grande do Sul pela produção do charque (carne seca), se fortalecendo enquanto uma das capitais pastoris do campo. A produção do charque e, posteriormente de produtos agrícolas

\footnotetext{
${ }^{6}$ O termo "agonia” é utilizado por Nunes( 2005) para fazer menção à uma temporalidade lenta de desconstrução das ferrovias brasileiras. Eckert (2012) também se refere a agonia dos habitante da vila mineira La Grand Combe, que viam o trabalho, base de suas referência identitárias, desaparecer pelos imperativos de "modernização da profissão".
} 
como a soja, escoava pelas ferrovias. Atualmente, Pelotas é a a quarta maior cidade do estado do Rio Grande do Sul, com aproximadamente 400 mil habitantes e localizada a cerca de 250km da capital, Porto Alegre.

As memórias urbanas ganharam força interpretativa a partir da convergência com outro campo de saberes, o da Antropologia Visual. Mediante os ensinamentos das antropólogas Ana Luiza Rocha e Cornelia Eckert, busquei a "compreensão do fluxo fabulatório das imagens que ancoram os jogos da memória” (Rocha \& Eckert, 2015b: 169). Esse fluxo fabulatório converge no conceito de "duração", que diz respeito aos “esforços de continuidade" (Bachelard, 1988) dos habitantes das cidades frente a finitude do tempo. A duração é atravessada pelo conceito de "identidade narrativa" (Ricoeur, 1991) que atribui ao ato criador de narrar a si mesmo como sinônimo de durar no tempo. O etnógrafo da duração também é um narrador (Rocha \& Eckert, 2005) que, mediante a interlocução etnográfica, acessa os esquemas de encadeamentos dos temporais e as rítmicas com as quais são articulados os tempos vividos e pensados dos sujeitos de pesquisa.

Na perspectiva das etnografias da duração as memórias do trabalho na sociedade contemporânea, acessadas a partir das narrativas dos narradores(as) envelhecidos, ganham novos horizontes imagéticos e etnográficos:

Como argumentar sobre o trabalho no fluxo do tempo, senão na experiência temporal de quem praticou, agiu, viveu essas transformações na multiplicidade dos ritmos cotidianos, os grupos trabalhadores urbanos no presente? (Rocha \& Eckert, 2015a)

Ainda nesse entendimento, as composições da memória são habitadas por imagens em seu sentido amplo: imagens narrativas, sonoras, fílmicas, olfativas, fotográficas.... Por essa razão, na Etnografia da Duração, as imagens são dados etnográficos, mediante o acesso às narrativas, aos acervos públicos, privados, pessoais e digitais. São métodos de pesquisa e de produção no trabalho de campo. São instrumentos éticos de colaboração e restituição. São suportes para a compreensão e interpretação dos fenômenos sociais. São conceitualmente pensadas e tem uso nas políticas do cotidiano, ao serem engajadas nos projetos e trajetos antropológicos compartilhados.

\section{Convergências: Envelhecimentos, políticas, durações e imagens}


O envelhecimento, na chave interpretativa das etnografias da duração, diz respeito à "vulnerabilidade do ser no tempo que se esvai” (Eckert \& Rocha, 2013b; 157). Não se trata unicamente da degradação de um corpo físico: o fenômeno envolve mais amplamente a descontinuidade dos tempos vividos e os minuciosos "esforços" (Bachelard, 1988), cotidianos e "teimosos" (Certeau, 1994), de narrar a si mesmo, mediante a atividade mnésica criadora ${ }^{7}$. Tratando-se, neste caso, de sujeitos pertencentes à uma comunidade de trabalho, o envelhecer percorre as tensões da lógica da sociedade de mercado. $\mathrm{O}$ envelhecer nesta sociedade salarial e industrial representa $\mathrm{o}$ momento de saída da vida produtiva e da desvalorização da pessoa idosa (Bosi, 2006).

Dado o reposicionamento da velhice nas sociedades contemporâneas (Debert, 2012) e “a questão previdenciária” estando no “centro do debate econômico” (Félix, 2016: 241) os estudos antropológicos do envelhecimento ganham importância e consistência. A “crise na sociedade salarial” (Cogley, 2007: 123) e do estado de bemestar, transformou os idosos em provedores, assumindo as responsabilidades de auxiliar a família, acionando redes de "solidariedade privada” ou sendo protagonistas suas lutas sindicais e nas carreiras políticas (Simões, 2004: 31). Os aposentados apropriam-se e ressignificam os espaços da urbe contemporânea, fazendo vibrar (Nunes, 2013).

Conhecendo esse campo temático, parti de uma acepção não cronológica da memória e do envelhecimento e intencionei interpretar as durações dos ferroviários aposentados frente ao processo de crise das ferrovias brasileiras. O conceito de crise vem da influência "teórico-etnográfica” (Peirano, 2014) do estudo de Cornelia Eckert entre os mineiros de carvão em Charqueadas, Rio Grande do Sul (1988) e em La GrandCombe França (2012). De acordo com Eckert, a crise é uma "ruptura temporal dramática” dos tempos vividos e ritmados pelo trabalho. A antropóloga buscou as temporalidades articuladas no "tempo do narrar" dos aposentados e demais moradores da vila mineira. Aquele núcleo urbano havia sido radicalmente transformado: uma transição entre a rítmica conduzida pelo trabalho operário mineiro, transformou-se no cotidiano de uma vila "letárgica” (idem: 74), com a predominância da população envelhecida. Neste cenário, sua opção foi evidenciar as estratégias dos entrevistados de conceder ritmo à vida cotidiana - frente às descontinuidades - reconhecendo as práticas e narrativas de uma comunidade de trabalho (idem: 90), em suas lógicas de durar no tempo (Bachelard, 1988).

\footnotetext{
${ }^{7}$ Ao utilizar o termo "criadora", estou remetendo tanto ao fato da duração ser concebida enquanto "obra" (Bachelard, 1988), como a uma disposição fantástica, imaginativa e criativa da memória (Durand, 1980).
} 
Com essa inspiração, dei atenção para a pluralidade de imagens constitutivas das identidades narrativas dos ferroviários e de seus esforços de permanecer em um tempo que se apresenta como descontínuo em diferentes matizes (aposentadoria, velhice, crise na ferrovia). Enfoquei seus projetos, seus engajamentos, seus anseios por manutenção da memória coletiva. Visando narrar esse trajeto de investigação, organizei o artigo em dois eixos:

a) Evidencio a “indignação ferroviária” e a “temporalidade da denúncia”, isto é, como as maneiras de agir dos envelhecidos, estão diretamente relacionadas com o “fim” desse modelo produtivo e à dissolução de sua comunidade profissional. Pretendo demonstrar que a crise tem uma direta relação com a duração dessas memórias, não como sua antítese, mas como própria característica basilar para os atos de permanecer sobre o tempo descontínuo.

b) Abordo os projetos de duração, desde os “desejos de memória” (Rapkiewicz, 2018) dos aposentados(as) que se materializam em diferentes ações. Neste eixo, apresento diferentes fragmentos narrativos do envelhecimento engajado e resiliente. Narro e avalio minha experiência, enquanto pesquisador em meu processo de inserção nas redes dos aposentados ferroviários pelotenses, ponderando sobre como os projetos intelectuais podem e devem ser aliados dos projetos de duração das populações urbanas. Nesse sentido, a Antropologia Visual e da Imagem tem papel preponderante, na restituição, na ética das imagens produzidas em campo e em seus usos, que fortalecem as durações.

\section{3 - A indignação ferroviária e a temporalidade da denúncia}

A memória narrativa, como ensinam dois mestres inspiradores da Etnografia da Duração, Gastón Bachelard (1988) e Paul Ricoeur (1991), depende dos usos criativos do tempo que fazem os sujeitos. A memória tem capacidade criadora, reinventa os momentos vividos, recriando-os no presente, explodindo a cronologia do tempo em uma multiplicidade de imagens.

Nesse mesmo sentido, dentre as diferentes narrativas ferroviárias que acompanhei, a recorrência de narrativas da crise $e^{8}$ foi acompanhada, também, de atos que estendiam o tempo do "fim” da RFFSA e do trabalho ferroviário, fazendo-o durar. Percebi que esta elasticidade temporal permitia a efetivação de gestos resilientes. A

\footnotetext{
${ }^{8}$ Termo que utilizei para designar o "falar da crise" como um gênero narrativo próprio, com rítmica, imagética e performance particular.
} 
temporalidade da crise potencializava uma temporalidade da denúncia. Denunciar a crise, por meio de narrativas, críticas e indignações eram formas êmicas da comunidade ferroviária se insubordinar frente a finitude.

Um dos espaços nos quais observei o frutificar desta temporalidade da denúncia foi o grupo da rede social Facebook, chamado "Ferroviários da SR-6 - Fotos"9. Nele, são compartilhadas diferentes imagens, desde fotografias de acervos pessoais, montagens, GIFS e vídeos encontrados na internet, que tem como conexão homológica a temática da ferrovia. Seguido cada uma das imagens compartilhadas, vários comentários em texto e até mesmo respostas com outras imagens, que são compartilhadas ou "curtidas”.

Observei uma constância de críticas relacionadas ao abandono e precarização da ferrovia no Brasil. Isto me leva a argumentar de que não existe uma oposição entre a crise e a duração. A denúncia da crise, o processo de evidenciar a precariedade é uma forma de duração, de ação sobre a descontinuidade do tempo e de manutenção do si mesmo. A crise é o que impulsiona a elaboração de argumentos críticos, denúncias, culpabilizações.

Luc Boltanski e Laurent Thévenot (1999) conceituam "moments critiques" (idem: 359), para fazer referência "at the same time, to the critical activity of the persons and to the unusualness of a moment of crisis” (Boltanski \& Thévenot, 1999: 359) ${ }^{10}$. São estas situações que exigem das pessoas a produção de "justificações" (idem), isto é, argumentos, ainda que estes sejam da ordem do banal e do cotidiano (“ordinary criticisms” (idem: 373). Comecei a perceber que estas denúncias sobre o fim da RFFSA e a precariedade das ferrovias, eram muitas vezes, imagéticas. A imagem, mesmo sem o acompanhamento de legenda, arregimentava grande quantidade de comentários de apoio àquela crítica cotidiana virtual e visual. Uma denúncia bastante potente são as imagens que mostram árvores ou capim sobre a linha férrea, impedindo, assim, a circulação de trens.

\footnotetext{
${ }^{9}$ Em 1975 foi criado o sistema de das SRs, antes era vigente o Sistema Regional com 13 divisões. A SR6 representa a superintendência regional - Porto Alegre.

10 “Ao mesmo tempo, as atividades críticas das pessoas e na anormalidade de um momento de crise”.
} 

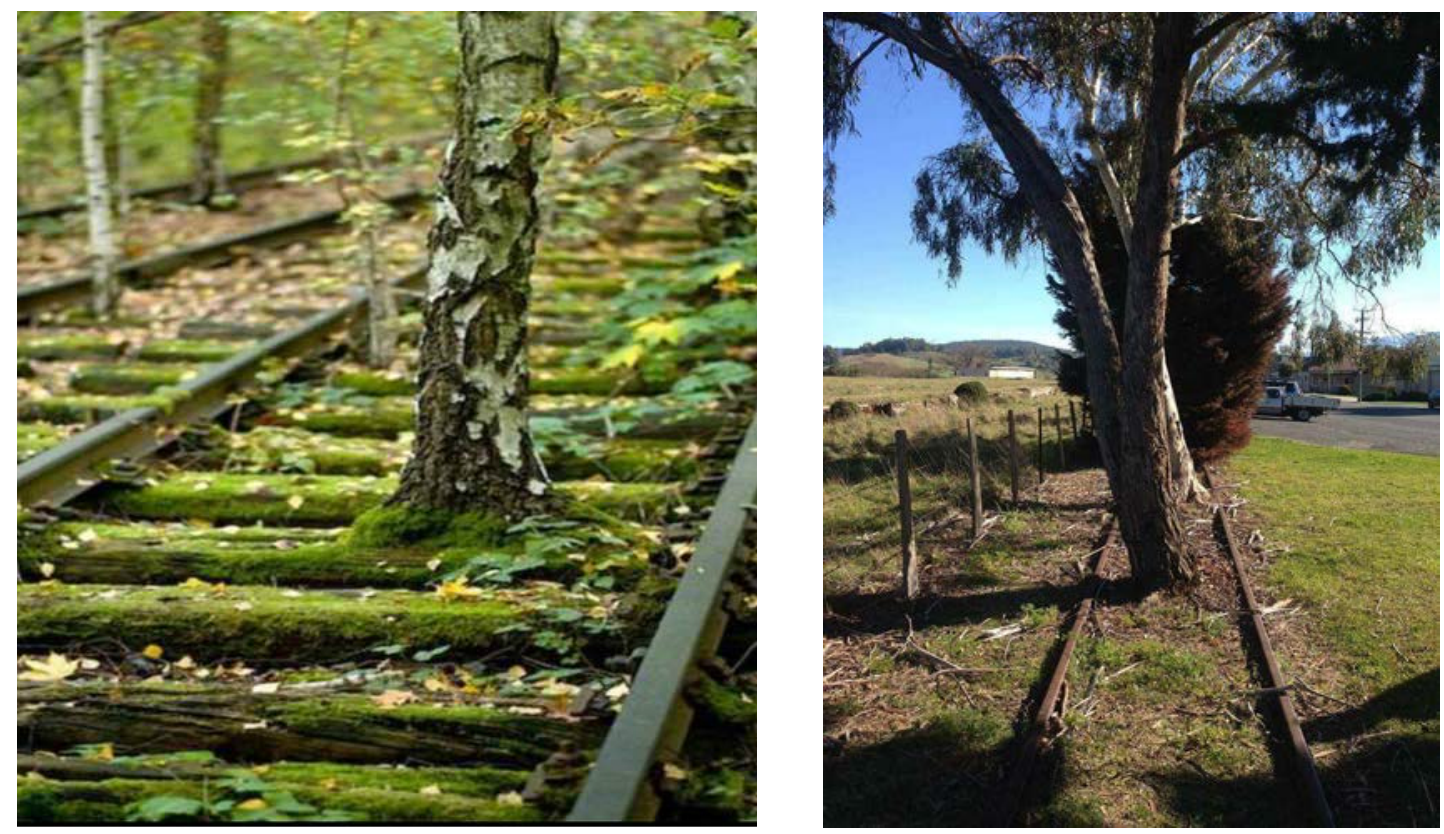

Figura 2: Imagética da crítica.

Fonte: Ferroviários SR-6 - FOTOS (Grupo Facebook).

Elas foram acompanhadas por diferentes comentários como: "Um absurdo”; "lamentável”, “Resultado da privatização da RFFSA!!!”; “Barreiras”; “que barbaridade”.

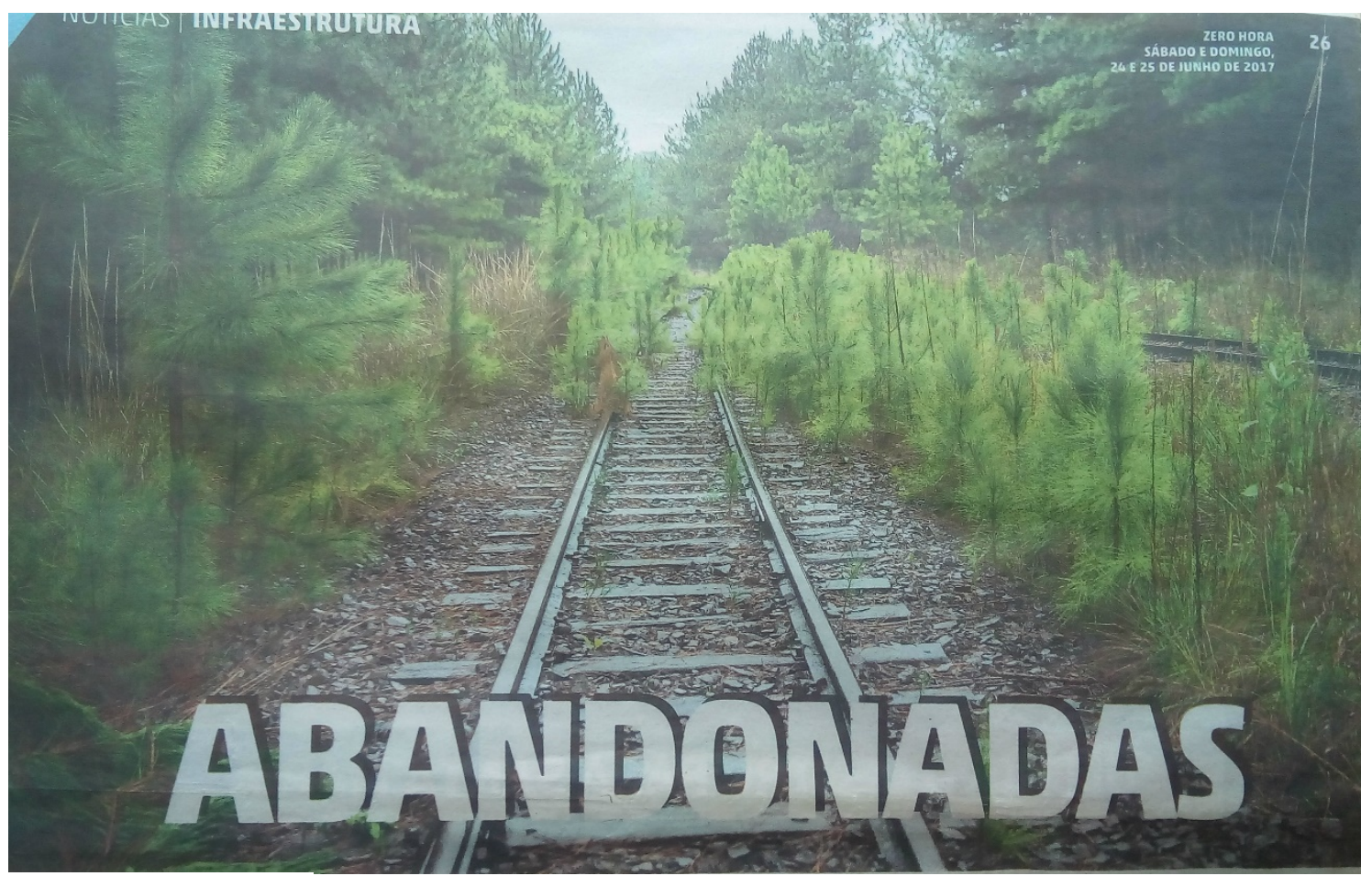

Figura 3: Abandonadas.

Fonte: Reportagem do jornal Zero Hora, em 24 e 25 de Junho de 2017.

Iluminuras, Porto Alegre, v. 20, n. 49, p. 83-121, maio, 2019. 
Diálogos críticos sobre a ferrovia e seu fim são recorrentes nas interações que tive com dois dos principais interlocutores de pesquisa, Rubem Medeiros e Orlando Chagas.

Rubem, nascido em 1937 em Cerro Chato, distrito da zona rural do munícipio de Herval (RS). Filho do ferroviário Bernardino Medeiros, assumiu a ferrovia logo após sair do serviço militar obrigatório. Foi sua primeira e única profissão. Trabalhou como Artífice de Via Permanente, trabalho braçal de revisão, reparo e instalação da linha férrea e posteriormente como Agente de Estação, serviço burocrático de licenciamento e autorização de tráfego de trens.

Já Orlando Chagas nasceu em 1958, Pelotas. Escolheu a Rede Ferroviária e não os Correios, outro dos concursos públicos que tinha sido aprovado na época. Trabalhou como manobrador até o final dos anos 1990. Após as privatizações, foi recontratado e direcionado ao posto de Maquinista, o qual desempenhou até 2012, quando se aposentou. Chagas é representante sindical em Pelotas do Sindicato dos Ferroviários do Rio Grande do Sul (SINDIFERGS).

Ambos trabalharam juntos, na Estação de Pelotas no final dos anos 1980 e, após aposentadoria mantiveram laços em virtude de questões previdenciárias. Ao longo do trabalho de pesquisa, me receberam e incluíram em suas redes como um amigo, se tornando parceiros interessados e engajados na memória coletiva ferroviária. A eles tenho o maior agradecimento e dedico meus escritos.

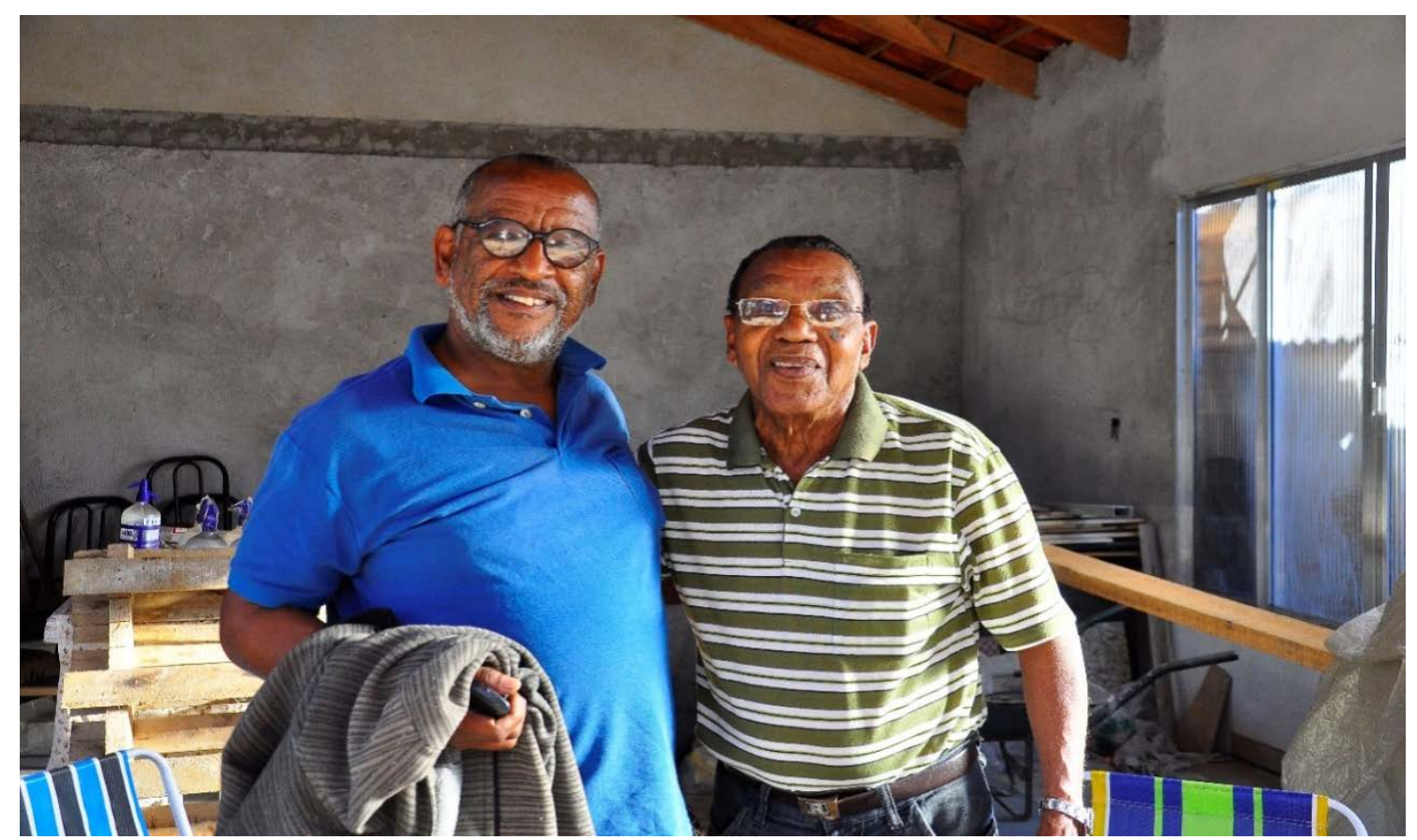

Figura 4: Orlando Chagas e Rubem Medeiros.

Fonte: Guillermo Gómez.

Iluminuras, Porto Alegre, v. 20, n. 49, p. 83-121, maio, 2019. 
Certa vez, reunidos no sindicato ferroviário, relembravam um "trecho" específico no qual a paisagem, vista das janelas do trem, era belíssima. A crise se manifestou pela passagem do tempo e pela “tomada” dos trilhos pelo matagal:

Orlando: "Não tem mais nada, as árvores tomaram conta, essa linha era a coisa mais linda, limpa! Tu pegava uma moto e ia daqui até Bagé, de moto, pela beira da linha. Agora tu não vai. Não anda nem a pé. O mato tapou, tem lugares que só tem aquela caverna de mato e só passa o trem. Tinha um lugar ali, o Rio Santa Maria ali, tu acompanhava um rio, tu via aquele baita rio!! Agora o mato não deixa tu olhar o rio. E a ALL não limpa a linha!”

Rubem: “Ah, antigamente, quando era da Rede, era tudo limpo... (Outubro de 2016).

Quando refleti sobre como se expressava este tipo de crítica e percebendo como ela era uma manifestação contrária à uma ação da natureza, coube uma passagem de Tim Ingold (2012):

Deixados ao léu, os materiais fogem do controle. Potes se quebram, corpos desintegram. Esforço e vigilância são necessários para manter as coisas intactas, sejam elas potes ou pessoas. O mesmo vale para o jardineiro, que deve estar sempre vigilante para impedir que o jardim se transforme numa mata. A sociedade moderna, é claro, tem aversão ao caos. Mas por mais que ela tenha tentado, através da engenharia, construir um mundo material à altura das suas expectativas - ou seja, um mundo de objetos discretos e bem ordenados -, suas aspirações são constantemente frustradas pela recusa da vida em ser contida. Podemos pensar que objetos têm superfícies externas, mas onde quer que haja superfícies a vida depende da troca contínua de materiais através delas (Ingold, 2012: 36-37).

O jardineiro, sempre vigilante, relembra o trabalho do "Tuco", um personagem ambíguo do universo ferroviário. Este apelido era dado para os trabalhadores do setor de Via Permanente, associados ao uso da força física nas tarefas de conservação da linha férrea. O “Tuco”, em algumas situações narrativas, pode ser definido como um animal, integrado à natureza e a seu tipo de atividade:

tem um bicho, na cidade não se vê esse bicho, ele vive no mato, no campo, e ele tá sempre cavando - e quando ele tá cavando ele faz assim: “tuc, tuc, tuc!”. E o Tuco, quando tá socando o dormente, também faz assim “ãhn, ãhn, ãhn! (Gómez \& Magni, 2017: 109).

Em outros casos, ele é o símbolo do ferroviário moderno, o operário, que evita que a linha seja tomada pelo capim. Aqui a linguagem é importante, são expressões de um conflito explícito, na qual a natureza é sujeito ativo: “as árvores tomaram conta”; “o mato não deixa tu olhar o rio"; “O mato tapou” [grifos meus]. Se para Ingold a natureza é o símbolo da irredutibilidade e da vida, para o ferroviário, a morte se coloca quando a natureza “toma conta”. O crescer do verde é interpretado como “absurdo" e 
"barbaridade". Os metais e o construído humano constituem "a vida” desta comunidade ocupacional. Ao mesmo tempo, a acusação recai sobre as empresas privadas (A.L.L.) e o mato aparece como signo mais brando do descaso que a desestatização promoveu.

Nas redes sociais as denúncias se transformam em uma ação coletiva. A duração do si mesmo ganha densidade com as memórias vibrando coletivamente (Halbwachs, 2006). Uma duração que se efetiva por meio das críticas à precariedade, como evidenciam outras manifestações:

"Ferroviários (AS): Precisamos criar uma FRENTE AMPLA EM DEFESA DO PATRIMÔNIO FERROVIÁRIO NO RS... Mobilização já!”

\begin{abstract}
"Se pautarmos por esta ótica do "não adianta mais", não sobrará mais nada, Airton. Temos um acervo muito grande e muita coisa pode ser salva ou recuperada. Está em nossas mãos, já que aguardar pela iniciativa de gestores e administradores públicos, pouco adiantará. Este patrimônio é nosso, legado de décadas de relevantes serviços prestados pela briosa classe ferroviária da VFRGS/RFSSA. Contamos com a participação e o incentivo do amigo. Grande abraço!”
\end{abstract}

Existem outras manifestações da memória coletiva que vibram nas redes sociais virtuais, vinculadas a uma memória afetiva e do sensível (Rouchou, 2009) e de pertencimento.

\begin{abstract}
"Adeus velho Amigo Azul e Branco, último Trem de Passageiros deixando Santa Maria-RS, o dia que ninguém queria que chegasse, sua partida levou muitas pessoas ferroviários ou não as lágrimas ao ver ele partir, quem sabe um dia ainda voltarás nem que seja em outras cores, tenha certeza nós choramos por tua partida, J R.”

"Gente, se eu falar pra vocês que fico emocionada só de ver essas fotos de estações e trens que são postadas no grupo, dá pra acreditar? Lembro muito do meu pai e da minha infância!”

"Não é só tu não, acredito que é este o sentimento da grande maioria dos Ferroviários, pois nós sempre fomos uma família muito emotiva.”
\end{abstract}

Estas ações, enquanto manutenções da memória coletiva, contam com algumas características peculiares das informações que circulam na internet, em redes como o Facebook.

O avanço da tecnologia da informática e das redes eletrônicas (..). tende a constranger os lugares "realistas" da memória ao confrontar os sujeitos modernos com ubiquidade, a simultaneidade, a distribuição irradiada e massiva de informações” (Rocha \& Eckert, 2015: 164)

A primeira delas é a efemeridade do registro. Os dados não estão ali para serem acervados para as futuras gerações. A segunda é a constante renovação e a periodicidade diária, fatores que produzem uma relação ímpar com a memória coletiva. Este uso êmico das imagens, permite que todos os dias se esteja relembrando, discutindo, 
denunciando assuntos relacionados à ferrovia. Trata-se de uma rítmica singular da manifestação da duração deste grupo profissional.

Os ferroviários, ferroviárias e famílias, por meio das redes sociais online, estão realizando também uma prática restitutiva. Essa restituição é, ao mesmo tempo, endógena e pública, com temporalidades e formas de operação próprias do Facebook. Jean Segata (2016) a partir de sua pesquisa na rede social Orkut, percebeu que

\begin{abstract}
havia nele dinâmicas que mobilizavam a formação de grupos de antigos amigos, a partir da inscrição em comunidades que em razão de eventos ou lugares dos quais se havia separado, por tempo ou distância física. Aparecia aí a velha escola, o bairro ou a rua da infância, a banda preferida, etc. Ao invés de sair do local e ganhar o mundo, havia um investimento em "voltar" e o tipo de dinâmica de se inscrever nesses espaços e se adicionar a amigos, produzia um feixe de relações bastante circunscrito que punha em questão a ideia de rede global (Segata, 2016: 99).
\end{abstract}

Se a escola, o bairro e a rua são quadros sociais da memória (Halbwachs, 2006) que potencializam o estabelecimento de vínculos nas redes sociais, o que dizer do trabalho ferroviário que coincide com as relações de moradia, trabalho e afeto, por meio de seu sistema de organização e arregimentação da mão de obra? Como afirmou Claudia Turra Magni, no GT de imagens da ANPOCS que participávamos juntos ${ }^{11}$, a ideia de rede, para a comunidade ferroviária, está “consolidada na memória, muito antes da web”.

\title{
4 - Projetos de duração desde os “desejos de memória”
}

Ao se entrar em contato com aposentados ferroviários logo se percebe o que o antropólogo e pesquisador da memória ferroviária sul brasileira Yuri Rapkiewicz chamou de “desejos de memória” (Rapkiewicz, 2018: 143), isto é, diversas ações visando a manutenção da memória coletiva, profissional e afetiva dessa comunidade ocupacional. Rapkiewicz, ao perceber as posturas dos ferroviários(as) preocupados com suas memórias, cunhou o conceito de etnocolecionismo:

\begin{abstract}
A partir do entendimento que etnocolecionismo seja uma prática de colecionamento engajado, motivado por finalidades coletivas, de conotação pública e política. Assim, a categoria que pretende horizontalizar a prática do antropólogo colecionador ao dos interlocutores (também colecionadores) emerge enquanto classificação de uma motivação (e negociação) subjacente ao ato de colecionar. Etnocolecionadores,
\end{abstract}

11 GT 14 - Imagens e Ciências Sociais: experiências de ensino e pesquisa. Coordenação: Ana Lúcia Ferraz (UFF) e João Martinho de Mendonça (UFPB). O trabalho completo conta nos anais do evento, conforme (Magni \& Gómez, 2017)

Iluminuras, Porto Alegre, v. 20, n. 49, p. 83-121, maio, 2019. 
logo, seriam aqueles que compõem narrativas e reúnem materiais temporais, através do acúmulo de experiências, papéis e objetos. (Rapkiewicz, 2018:143-144) ${ }^{12}$

Me junto a essa postura etnográfica que indica a importância do cultivo da memória nas sociedades contemporâneas e como os diferentes atores desse contexto específico (ferroviários, patrimonialistas, antropólogos, museólogos) podem e devem dar vazão à projetos colaborativos, calcados na interlocução ética e restitutiva. Com isso, indicamos, enquanto comunidade interpretativa, a politização da memória, o que nos faz perceber as atitudes dos aposentados como militâncias cotidianas a favor da preservação do si mesmo e do coletivo frente a inconstância do tempo. Nesse sentido, a Antropologia Visual tem um papel preponderante:

Em termos epistemológicos, o (a) antropólogo(a) se oferece ao papel de "guardião" da memória dos grupos com os quais trabalha, ou de agente de sua reatualização e retransmissão (mediando redes de sentido, de intepretação, de comunicação)”.

(Rocha \& Eckert, 2015b: 179)

Assim, passarei a narrar fragmentos do meu processo de inserção nas redes do envelhecimento ferroviário, tanto na proposição como no reconhecimento dos projetos êmicos e, principalmente, na constelação de alianças ${ }^{13}$ em torno das iniciativas a favor da duração da memória coletiva.

Iniciei o contato com a comunidade ferroviária partir do Memorial da Estação Férrea (MEF), projeto da Universidade Federal de Pelotas, coordenado por Claudia Turra Magni. A proposta surgiu de uma iniciativa do poder público municipal, na figura da Secretaria de Cultura de Pelotas, com intenção de patrimonializar um prédio histórico, a Estação Férrea de Pelotas. A equipe de alunos, da qual eu fazia parte, coordenados pela professora Claudia, tinha por objetivo realizar uma pesquisa etnográfica que pudesse fornecer substrato à formulação do Memorial da Estação Férrea. Em dezembro de 2018, data de escrita desse texto, o Memorial ainda não foi instalado na parte central da estação, conforme o projeto esboçado pelo poder público, ainda em 2015. Esse fato causou manifestações de indignação dos interlocutores: “nós somos ferroviários, nós que levantamos aquilo ali e nem os ferroviários entram lá, acho ridículo” (Rubem Medeiros- 15/12/2017).

\footnotetext{
12 Interpreto o conceito de Etnocolecionismo conhecendo duas influências da antropologia de Rapkiewicz: a dupla condição de narrador do interlocutor e do antropólogo (Rocha \& Eckert, 2005) e, em um campo mais amplo, da Enografia da Duração com diálogo e fricção com a contemporânea antropologia do patrimônio.

${ }^{13}$ A ideia de projetos colaborativos tem, na epistemologia ética da Antropologia Visual, sempre a inspiração e referência do trabalho de Jean Rouch (Gonçalves, 2008).
} 
Ainda assim, a pesquisa que fundamentou o projeto, concluída em 2015, apresentou a contribuição da universidade para a realização do Memorial, com a produção de um vídeo-documentário, ensaios fotográficos e de banners temáticos que agregam narrativas e fotografias. ${ }^{14}$ Especialmente sobre o conjunto de banners, que são organizados no formato de museu de rua, é preciso falar da relação destes com Orlando Chagas. Após a inauguração do MEF na Estação Férrea de Pelotas em 2015, e de sua ida para o Mercado Central, no início de 2016, Orlando tomou a frente do projeto, articulando a movimentação dos banners para a sede do Sindicato dos Trabalhadores em Empresas Ferroviários no RS (SINDIFERGS), em Porto Alegre. Nando negociou com as lideranças sindicais a realização de uma cerimônia para a inauguração do MEF no SINDIFERGS, que "para ter gente”, aconteceu no mesmo dia da posse da nova diretoria. No dia 7 de abril de 2016, um dia antes da cerimônia de posse, com o auxílio de Dorildes Begnini (Departamento de aposentados e pensionistas) e demais funcionários do SINDIFERGS, fizemos a montagem da exposição.

Após a montagem, Orlando me apresentou o acervo de livros e documentos ferroviários, bem como ferramentas, vestuários e miniaturas, disponíveis no SINDIFERGS. Ele me mostrou o rádio, o principal instrumento do manobrador, que o utilizava para se comunicar com o maquinista e informar as manobras que o trem deve fazer, ao chegar em uma determinada estação.

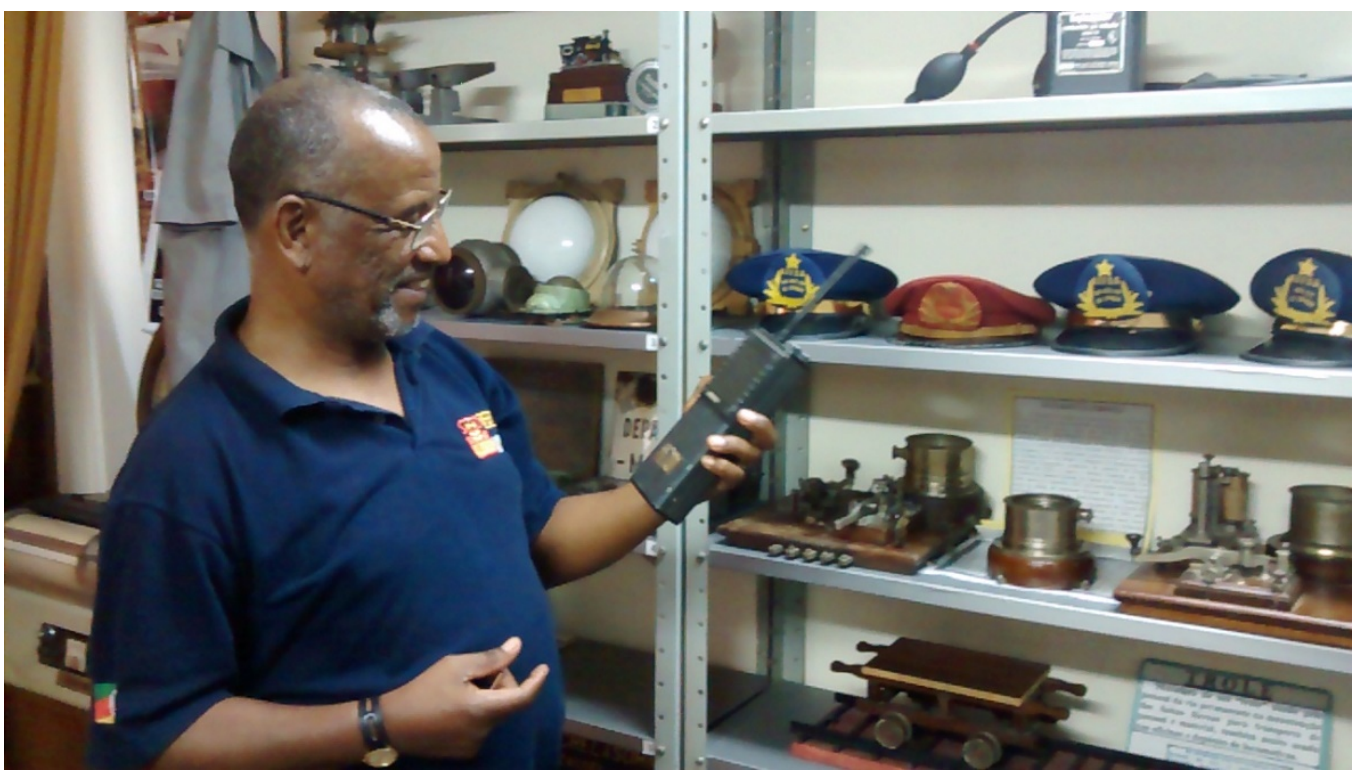

Figura 6: Orlando no memorial do Sindicato dos ferroviários em Porto Alegre. Fonte: Guillermo Gómez.

${ }^{14}$ O Memorial da Estação Férrea, assim como outros projetos do LEPPAIS, podem ser consultados em: https://wp.ufpel.edu.br/leppais/projetos/pesquisa-e-extensao/

Iluminuras, Porto Alegre, v. 20, n. 49, p. 83-121, maio, 2019. 
No dia 8 de abril de 2016, após as falas de João Calegari, Jair Morais e demais lideranças sindicais, que assumiam naquele dia o SINDIFERGS, nos foi cedido um momento para ocuparmos a mesa, transmitindo o vídeo-documentário "Vida nos Trilhos” e apresentarmos a pesquisa e seus colaboradores, inaugurando a presença dos banners na sede do sindicato ferroviário.

O MEF ficou exposto até o dia 21 de outubro de 2016, data também pensada em razão da realização de uma reunião sindical significativa, que reuniu ferroviários de diferentes regiões do Rio Grande do Sul, que estavam ali para serem atualizados em relação a questões salariais. Nesta ocasião, optei por não falar no microfone, pois este estava aberto para os ferroviários se manifestarem e fiquei ouvindo suas diferentes manifestações. Assim, fui conversando com as pessoas que se agrupam próximas dos banners afixados nas paredes, apresentando a pesquisa e conhecendo suas impressões sobre o material que se despedia do Sindicato naquele dia.
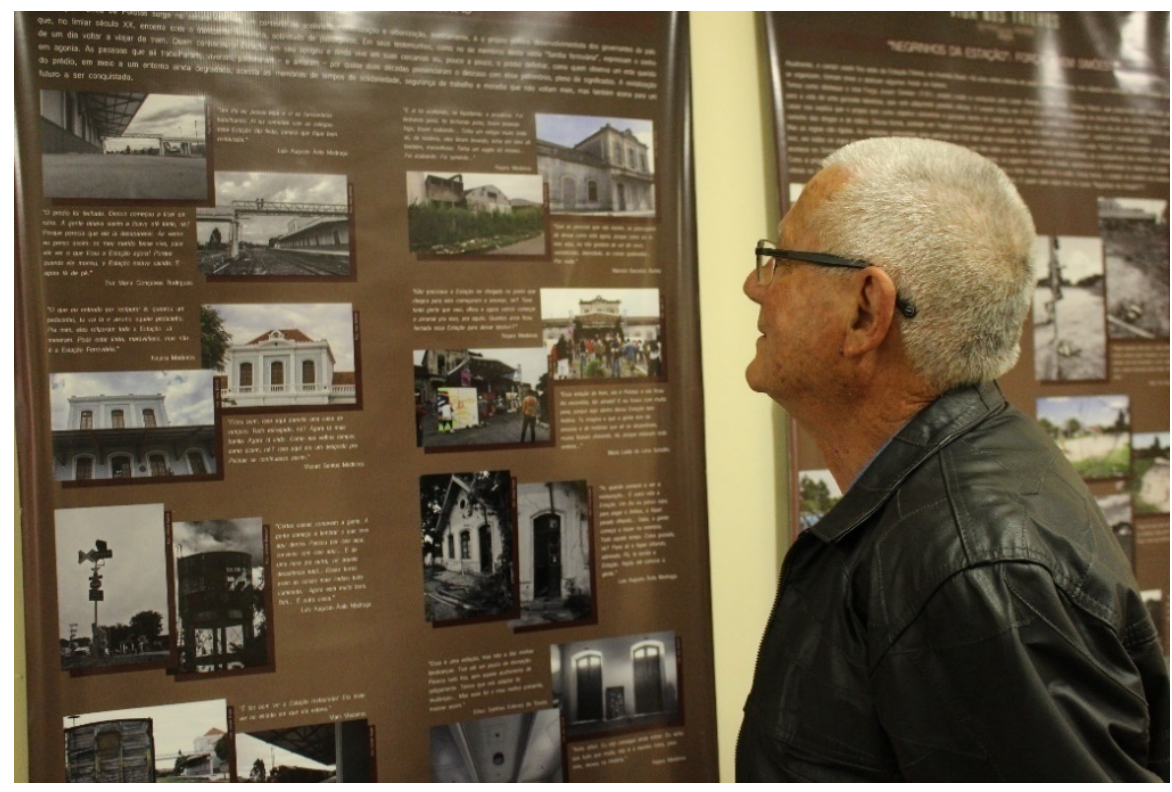

Figura 7: MEF no SINDIFERGS, último dia - 21/08/2016. Fonte: Guillermo Gómez.

O vínculo de Orlando Chagas com o MEF transcende a materialidade dos banners e sua circulação, transbordando para sua elaboração de conceito de memorial, que redundaram na iniciativa de Chagas em realizar uma série de procedimentos de reflexão sobre a preservação da memória ferroviária. Percebi atitudes como as de passar a guardar suas fotografias, me pedindo que lhe enviasse pelo WhatsApp as que eu produzia no trabalho de campo, planejando a confecção de um quadro em sua garagem com a constelação desses diferentes momentos e encontros. 


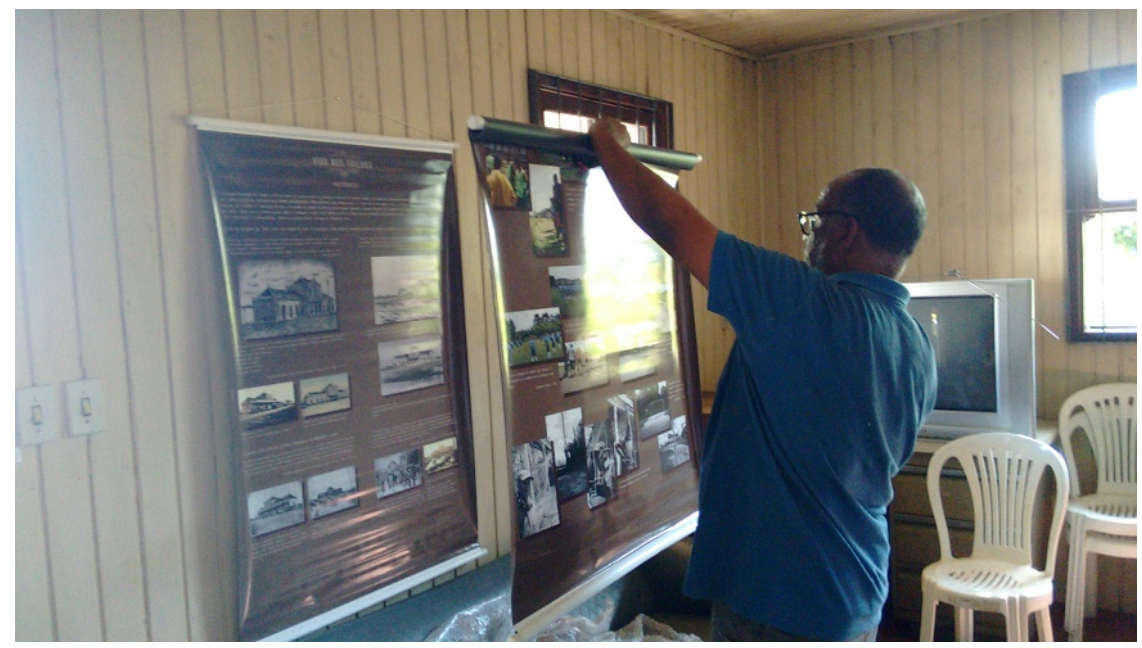

Figura 8: Orlando montado o MEF no sindicato de Pelotas. Fonte: Guillermo Gómez.

Chagas, ao longo do tempo de interlocução (2015-2018) aumentou o interesse pelos procedimentos e ritos acadêmicos. Esteve presente, junto com Rubem, na defesa de dissertação da antropóloga Andressa Pereira, da qual foi um interlocutor ativo. Durante a defesa, demonstrou seus conhecimentos sobre a sonoridade do trem, tema da pesquisa de Pereira (2017), mencionando os tipos de apitos e os códigos de serviço. Orlando me questionou diversas vezes sobre procedimentos de avaliação da dissertação [ver epígrafe] e sobre quem estará na banca. Em outra ocasião, quando estávamos reunidos no LEPPAIS, Orlando abordou a professora Claudia: "não tem nenhum aluno teu que queira pesquisar a ferrovia? Encontrei várias fotos sobre acidentes ferroviários...” (15/12/2017).

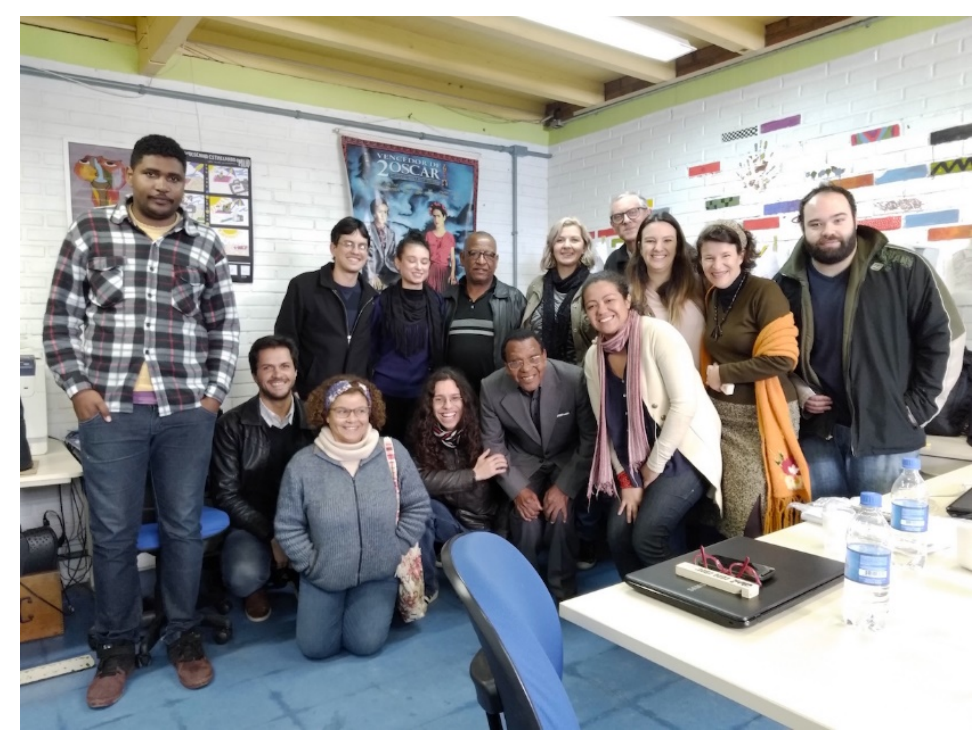

Figura 9: Defesa de Andressa Pereira, com a presença de Orlando e Rubem.

Iluminuras, Porto Alegre, v. 20, n. 49, p. 83-121, maio, 2019. 
Fonte: Hamilton Bittencourt.

\title{
4.1 - Nos trilhos da história de Paulo Nilton de Carvalho
}

Foi seguindo algumas dessas inspirações em nosso trajeto que Orlando sugeriu que eu, Andressa e Rubem conhecêssemos Paulo Carvalho, ferroviário aposentado, morador da cidade de Rio Grande. ${ }^{15}$ Este senhor é conhecido como uma "figura” entre os ferroviários, por ser uma pessoa carismática e ter manifesta militância pela memória ferroviária.

“Seu Paulo”, como é conhecido, já ministrou palestras e divulgou exposições, de painéis confeccionados com fotografias próprias e objetos de seu acervo pessoal, para Tupanciretã $^{16}$, Gramado ${ }^{17}$, Rio Grande, e diversas outras cidades do Rio Grande do Sul (Calloni, 2010). Uma apresentação de Paulo, em suas próprias palavras, já delineia sua característica de sentinela da memória ferroviária:

\begin{abstract}
Cumprimento o radialista da RádioCom de Pelotas ${ }^{18}$ e dizer que é uma satisfação muito grande de dar alguma opinião sobre minha vida ferroviária. Eu nasci na cidade de Uruguaiana, o pai era de origem ferroviária, só nasci em Uruguaiana, que o pai trabalha em uma estação próxima e com 7 dias de vida, uma semana de vida, eu vim morar dentro de um vagão, porque a estação que o pai morava estava em construção... E ali começou uma paixão ferroviária, acho que entrou no sangue né, com 7 dias. Então nessa vida ferroviária com o pai. E ele trabalhou 40 anos na ferrovia, né? Eu já com 10, 12 anos já aprendi o telégrafo, paralelo com o estudo. E com 17 anos eu entrei na ferrovia em Santa Maria, até já era telegrafista, mas enquanto aguardava vaga iniciei como auxiliar de carpinteiro, depois trabalhei um ano ajudando o maquinista e manobrando. Até chegar a minha vez, em 1958 eu entrei na função de telegrafista nas estações. E nessa caminhada toda eu sempre tinha o costume de guardar alguma coisa, e daí fui trabalhando, trabalhei 36 anos e meio na ferrovia. Quando eu me aposentei eu tinha uns 3500, 4000 fotos de gravura e eu achei que deveria fazer uma exposição e mostrar, até eu fazia uma exposição para o pessoal aposentado e agora nos últimos 10 anos eu tenho feito exposição itinerante. É um hobby. Não tem lucro nenhum não cobro nada, não tenho patrocínio. Eu faço por amor a ferrovia mesmo (Paulo Carvalho, em entrevista concedida a Glenio Rissio).
\end{abstract}

Nessa narrativa, percebemos o comprometimento do ferroviário, o que o torna um verdadeiro "guardião da memória” (Le-Goff, 1990). Seguindo o convite de Orlando, viajamos até o município de Rio Grande, no dia 26 de junho de 2017, para conhecer o "homem-memória" (Le-Goff, 1990) e nos inteirar de sua mais recente exposição. Na edição do jornal Zero Hora do final de semana de 24 e 25 de junho, havia

\footnotetext{
${ }^{15}$ Munícipio localizado há $50 \mathrm{~km}$ de Pelotas. Tem 200 mil habitantes. Possui porto com a quarta maior movimentação portuária do Brasil.

${ }^{16}$ Município do Rio Grande do Sul com aproximadamente 20 mil habitantes.

${ }^{17}$ Município da Serra Gaúcha. Tem aproximadamente 30 mil habitantes.

${ }^{18}$ Esta entrevista foi feita por Glenio Rissio e seu registro em áudio me foi cedido com a autorização de ambos para sua reprodução.
} 
sido publicada uma reportagem intitulada “Abandonadas"19 [Ver Fig.3] indicando que o transporte de cargas no estado do Rio Grande do Sul havia recuado 43\%. Fui lendo a matéria - que além do relato de crise, continha alguns causos, como de um trabalhador que descobriu que o pai mantinha uma família em outra cidade em razão de um acidente ferroviário - em voz alta. Chegando a Rio Grande, nos reunimos no prédio recém adquirido do sindicato dos ferroviários, que necessitava de reformas, pois havia sido interditado pelos bombeiros. Gilda Silva, que mora e trabalha com artesanato na cidade Rio Grande, coordenava a reunião.

'Seu’ Paulo chegou munido de um dos banners que divulgava sua exposição, um apito que simula o som de um trem e o mesmo jornal que eu havia levado, o dele dobrado logo na reportagem sobre a ferrovia, chamando atenção para o título, “Abandonadas”. Também estavam presentes membros da equipe convocada por Gilda, como Airton Gonçalves, responsável pela comunicação da praça do artesanato em Rio Grande, e Emir Duarte, que vende canetas, brindes, etc. Identifiquei este gesto de convidar diferentes participantes, enquanto uma atividade que mantinha a solidariedade da cidade, que se circundava e registrava a exposição de Paulo enquanto uma proposição coletiva. Como informou Gilda:

Convidei ele [Emir] para participar justamente para isso. Para que ele acrescente. Assim como o pessoal do artesanato da praça que vai vir, que não tem nada a ver com a ferrovia, mas são gentes aqui de Rio Grande que tão sempre unidos em alguma coisa. Então quando acontece alguma coisa assim, a gente procura puxar, porque um sobrevive ajudando o outro (Gilda - 26 de Junho de 2017).

A reunião, além de debater os itens de uma ata elaborada por Gilda, também serviu para a rememoração dos ferroviários, principalmente de Rubem e Paulo que, sendo da mesma faixa etária, relembraram acontecimentos, acidentes e regulamentos da Rede Ferroviária. Os dois trabalharam juntos, Paulo como Controlista e Rubem como Agente de Estação. Suas funções eram interligadas, Paulo organizava todos os trens do setor e Rubem autorizava, por meio do licenciamento de trens, os veíuculos que se movimentavam nos trechos que conectam Pelotas com outras regiões.

19 Disponível em: https://gauchazh.clicrbs.com.br/economia/noticia/2017/06/transporte-de-cargas-sobretrilhos-no-rs-recua-43-em-cinco-anos-9821776.html. Acesso em: 01 jul.2017. 


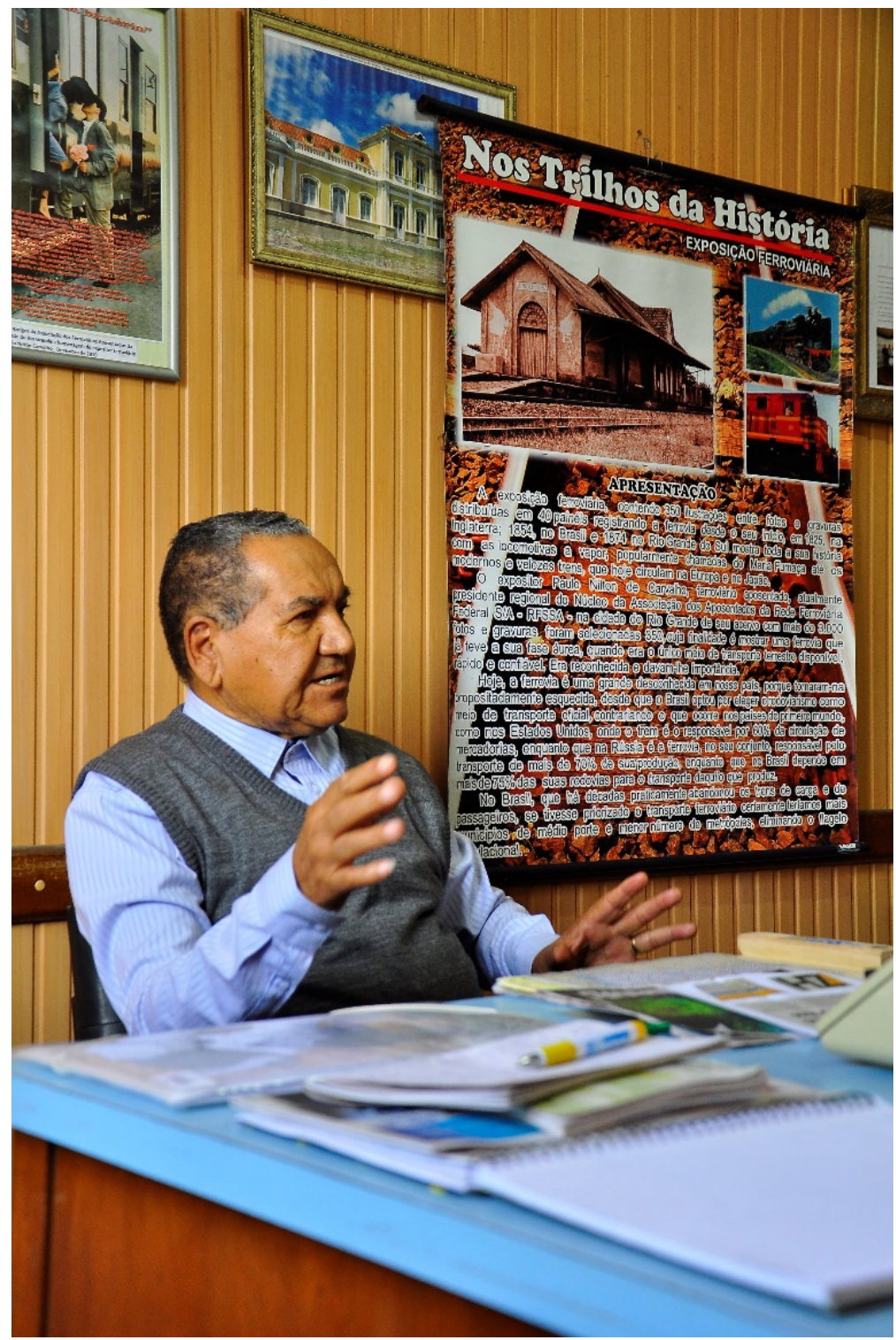

Figura 10: Paulo Carvalho Fonte: Guillermo Gómez.

Paulo nos contou sobre um livro publicado por seu genro, Humberto Calloni, professor da Universidade Federal de Rio Grande (FURG), intitulado "Nos trilhos da história da ferrovia: Entrevista com Paulo Nilton de Carvalho” (Calloni, 2010).

Faz 22 anos que tá casado com a filha, o namoro dele era o namoro antigo (riso) de visitar, né? E aí sempre a guria tava se arrumando. Hoje em dia não existe mais isso, facilita mais um pouco. Ele chegava lá em casa e eu ficava sempre constrangido, um professor, assim... Hoje não, hoje é uma pessoa sensacional! Como é que eu vou conversar com um professor? Com ferroviário eu posso conversar, mas com professor, né tchê! E aí eu conversei, dei um toquezinho de trem e ele gostou. Aí eu não tinha assunto e socava trem nele! [risos de todos] E ele gostava, elogiava, e eu dizia pra minha filha, olha esse cara quer te namorar e tá fazendo de conta que gosta de trem. Mas tava enganado, ele gostava. Aí eu contava as coisas pra ele e surgiu, vamos fazer um livro. E eu não, mas eu, livro, minha única escrita é 
ferrovia. Aí surgiu a ideia então de fazer no sistema de entrevista (Paulo Carvalho - 26 de junho de 2017).

O livro se organiza em 7 capítulos, cada qual representando uma entrevista concedida por Paulo a Humberto, organizados mediante uma temática da vida do ferroviária (As origens, As caixas d’água, As políticas, Os esportes e as exposições, os gibis, Acidentes na ferrovia, As brincadeiras e outras histórias). Sobre a exposição, Paulo deu detalhes de sua organização expográfica e dos itens que compunham seu acervo pessoal:

\begin{abstract}
Eu tenho uma locomotiva, que foi feita por um operário em Santa Maria e tenho uma Maria Fumaça feita por um operário aqui de Rio Grande, ele só fazia isso aí, era uma loucura. Eu ganhei um CD onde tem toda uma locomotiva funcionando e apitando. Aí eu escondo de baixo ali, eu levo o CDzinho. Aí os caras tão olhando pensam que é a máquina! (risos). O sino da locomotiva, a Maria Fumaça, por exemplo, era obrigatório, o maquinista era obrigado [a apitar], até sob punição, porque as cidades cresceram em torno da linha, né? Por exemplo, essa linha que vai pro lado de Pelotas, os dois lados, surgiram várias passagens de nível e essas passagens de nível ${ }^{20}$ seguidamente davam acidentes. Então o trem tinha que vir batendo o sino e apitando. E essa minha máquina faz isso. (Paulo Carvalho - 26 de junho de 2017).
\end{abstract}

No fim da reunião, tomamos um café com biscoitos trazidos por Gilda, agradecemos os diálogos e retornamos a Pelotas. No dia 30/09 de 2017 nosso quarteto (Rubem, eu, Andressa e Orlando) se deslocou novamente para Rio Grande, desta vez para prestigiar a exposição, já montada, na sala multiuso da Prefeitura de Rio Grande. Lá estavam Paulo Nilton e Gilda, os dois saudaram nosso grupo e logo em seguida, Paulo, com um crachá identificando-o enquanto expositor, nos guiou pelo saguão, atentando para detalhes dos materiais e artigos apresentados.

${ }^{20}$ Passagem de nível é quando a linha férrea se cruza com outra via, seja de carros ou de tráfego de pedestres.

Iluminuras, Porto Alegre, v. 20, n. 49, p. 83-121, maio, 2019. 


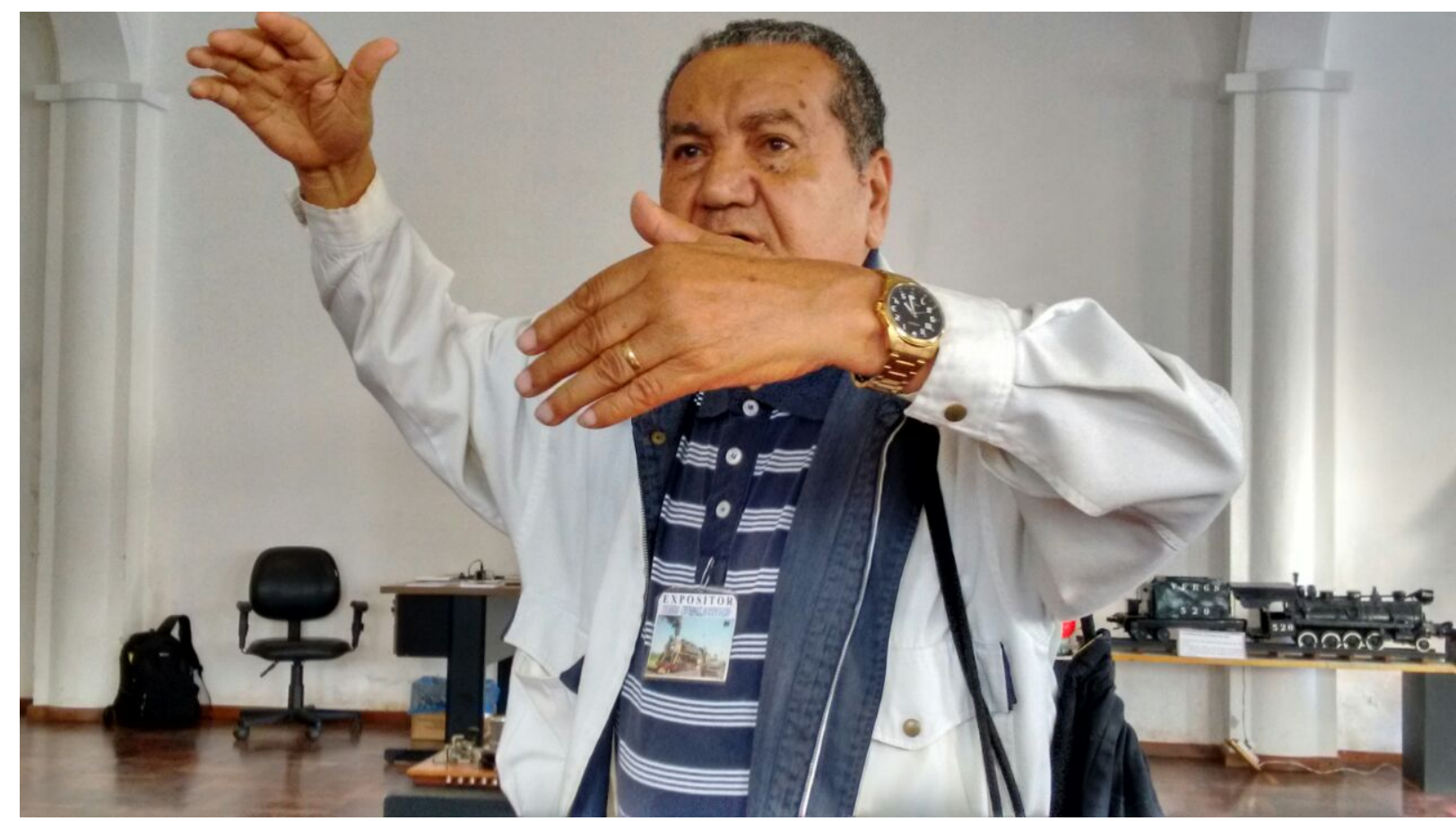

Figura 11: Paulo, o expositor. Fonte: Guillermo Gómez.

Na exposição, o que chamou mais atenção de Orlando e, principalmente, de Rubem, foram os instrumentos e vestimentas de trabalho. Rubem se empolgou com a presença do aparelho de telégrafo e constantemente me chamava a atenção, pois havia me falado daquele instrumento em outras conversas. Paulo mostrava uma cartela com o Código Morse, sistema de comunicação usado pelo instrumento de trabalho e refreando possíveis crenças de que “Ah, mas pra passar um telegrama levava um dia inteiro”, respondia: “Não, telegrafista para fazer exame tinha que transmitir 25 palavras por minuto e receber 25 palavras por minuto, se não, não era aprovado”.

O percurso da exposição prosseguiu, Paulo demostrando o funcionamento do carimbador de passagem e Rubem, comentando “eu trabalhei com isso aí, eu vendia passagem, né?”. Rubem também resolveu fazer seu próprio trajeto, me guiando e indicado "eu usei esses quepes aqui", disse ele, mostrando este componente do uniforme do Agente de Estação. Orlando propôs que Rubem posasse para uma foto utilizando o "seletivo", o telefone da RFFSA, dispositivo que utilizava cotidianamente enquanto Agente e solicitou que eu fotografasse a cena.

Na ocasião do encerramento da exposição, Gilda Silva enviou homenagens para Rubem e Orlando, com uma pequena "lembrancinha": um objeto de artesanato simulando os trilhos do trem e sobre de vidro com um breve texto de "honra ao mérito": 
“A cidade de Rio Grande agradece em reconhecimento por sua contribuição e dedicação a Rede Ferroviária, pois foi com homens como você que foi possível a formação desta história, que há de ser contada por muitas gerações.”

Refletir sobre uma exposição que tem como tema a memória do trabalho, relembra a preocupação posta por Henri-Pierre Jeudy (1990). Quando utensílios de trabalho são colocados e catalogados nas vitrines das disposições museais, não estariam ali expostos instrumentos de tortura do operário?

\begin{abstract}
A estética dos objetos técnicos e funcionais é compartilhada socialmente através desse ato de reabilitação que rende a reproduzir a autenticidade dos gestos perdidos. Mas a habilidade assim recuperada não é o signo da repetição e da morte? O fantasma do "saber operário" não frequenta essas grandes salas de atelier conservadas e cuidadas para a exibição do devir da cultura técnica. Tudo se torna tão belo nesse movimento de restituição das habilidades que o horror da exploração não se mantém nem mesmo como uma recordação ruim (Jeudy, 1990: 120).
\end{abstract}

A exposição ferroviária de Paulo, em minha interpretação, não contém necessariamente um horror oculto, embora tenham fluido, durante a pesquisa, narrativas nas quais convergiam imagens da exploração e opressão. Este não é um fator que deva ser ignorado em uma pesquisa sobre memória do trabalho, porém, a exposição descrita acima, articula o pertencimento à uma comunidade e a constituição de uma apresentação de si para os ferroviários aposentados. O orgulho de Paulo, enquanto expositor, faz com que esse interlocutor realize um “trabalho ferroviário” de memória e acervo e, prioritariamente, de compartilhamento do saber com o público. A reação de Rubem, sua identificação e o orgulho e demonstrar que ele havia manipulado, vestido e vivido os itens expostos, faz com que a memória do trabalho aja como "o sentido, e a justificação de toda uma biografia” (Bosi, 2006: 481).

Retornando a meu diário de campo, identifiquei um diálogo que tive com Rubem, quando regressávamos naquele dia à Pelotas. Quando perguntei quais suas impressões da exposição, ele disse que havia gostado e enfatizou a importância de "estar com um ferroviário" para ver a exposição e entendê-la: "se tu não fosse comigo ou o Nando, não saberia o que é aquilo”. O saber profissional passa a ser um mediador, um esclarecedor, um condutor de narrativas e um suscitador de imagens. 

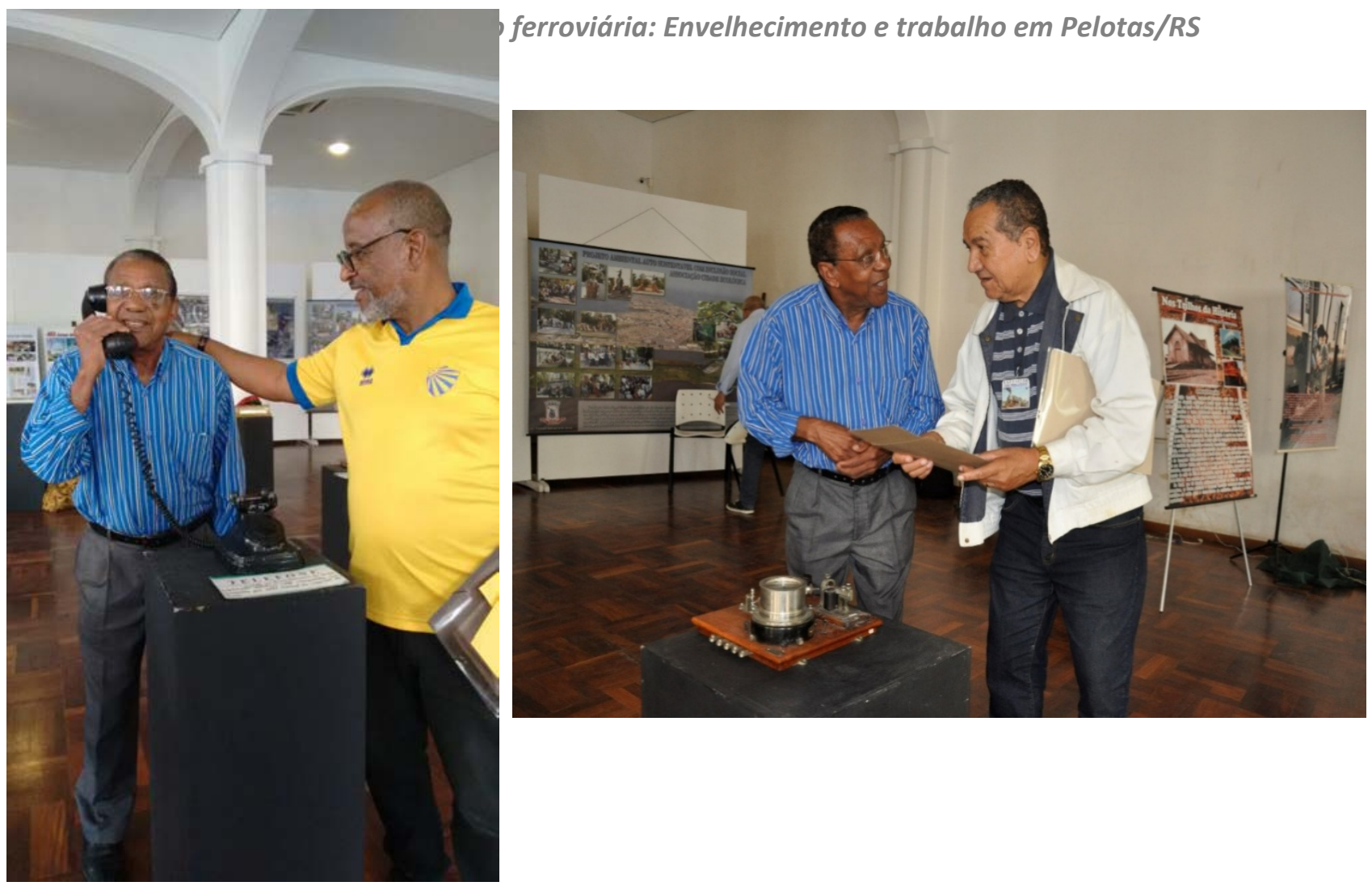

Figura 12 (esquerda) : Rubem e Orlando com o telefone seletivo

Figura13 (direita) : Rubem e Paulo com telégrafo e tabela com código Morse.

Fonte: Guillermo Gómez.

\section{2 “Cultura transmissível”: memórias ferroviárias na RadioCom}

Outra parceria que nos engajamos ao longo do trajeto de pesquisa foi a realização de programas sobre a temática na Radio Comunitária de Pelotas. A RadioCom, como conta um de seus fundadores, Glenio Rissio:

(...) começou em Rio Grande, com o pessoal do sindicato dos portuários. Eles que deram a ideia de fazer uma associação de sindicatos para fazer uma rádio comunitária, a gente foi lá conversou com eles, pegou a ideia deles e trouxemos pra cá, estatuto, essas coisas. O Silas, que tá aposentado, era o presidente do sindicato. Ele, junto com CPERS [Sindicato dos Professores Estaduais] vários sindicatos, montaram uma rádio comunitária lá em Rio Grande. Eles não tinham uma experiência de rádio, mas eles fizeram uma coisa nova. Praticamente toda nossa base tem a ver com eles. Só que, claro, sempre quem vai na frente tá sujeito a cometer erros, porque tá lá frente, numa coisa nova, e que com certeza tem situações que ele não vai saber lidar, por que é uma coisa nova. Foi o que aconteceu, eles não conseguiram manter a rádio e aí a gente, a partir da experiência deles, tanto positiva como negativa, a gente começou tem coisas que não podemos repetir, que não deu certo lá... Então foi assim que a gente montou nossa radio aqui. Isso é uma coisa que a gente e não esquece, a gente não pode esquecer, essa raiz, esse começo da nossa história. Por isso que é importante o registro (Glenio Rissio $-12 / 01 / 2018)$.

Iluminuras, Porto Alegre, v. 20, n. 49, p. 83-121, maio, 2019. 
Foi o recente ingresso de Glenio, 56 anos, no curso de Antropologia e Arqueologia da UFPel, que fez com que ele alicerçasse vínculos entre a Rádio Comunitária e as discussões antropológicas, o que resultou na criação do programa “Nós Nosotros, Antropofonias e Charlas da Radio Comunitária de Pelotas” de periodicidade semanal.

\begin{abstract}
A ideia do programa já, desde o começo quando a gente entrou no curso já se tinha essa ideia da possiblidade de ter um programa de Antropologia e Arqueologia dentro da rádio. (...)

(...) Essa relação da antropologia tá dentro da radio já há um bom tempo e ai quando eu entrei no curso, pô vamos fazer um programa né. Semanal. Aí levei a ideia pro pessoal, pessoal gostou. Foi na semana acadêmica que a gente trouxe a ideia. O pessoal gostou e uma equipe grande, uma galera que tá se empenhando, tanto alunos como professores. Na realidade a gente faz uma reunião durante a semana e no fim de semana gente faz o programa (Glenio Rissio, 2018 12/01/2018).
\end{abstract}

Assim, foi por meio do contato de Glenio com a professora Claudia Turra que se gestou a ideia de um programa sobre o Memorial da Estação Férrea. Eu soube disto por meio de um email de Claudia, me convidando e sugerindo que eu chamasse os ferroviários para participar. Acertamos as datas para uma reunião preparatória na sala do LEPPAIS, que foi realizada no dia 15 de dezembro de 2017.

Presentes Orlando e Rubem, assim como Claudia Turra, eu, Andressa Pereira, e os estudantes de antropologia Guilherme, Margo, Juliana e Fabrício Barreto. Discutimos a organização do programa, as principais temáticas e os eixos que guiariam a conversa. O programa, com duração de 1 hora e meia, contaria com a seguinte estrutura: após a abertura e apresentações, Claudia introduziria o tema do projeto MEF seus desdobramentos (15min), em seguida eu retomaria a história da ferrovia (15 min), seria realizado um intervalo e depois ouviríamos as narrativas dos ferroviários e suas reivindicações. A reunião também serviu de rememorações do processo de pesquisa iniciado em 2015 e também de denúncia da Estação fechada e inacessível aos ferroviários. 


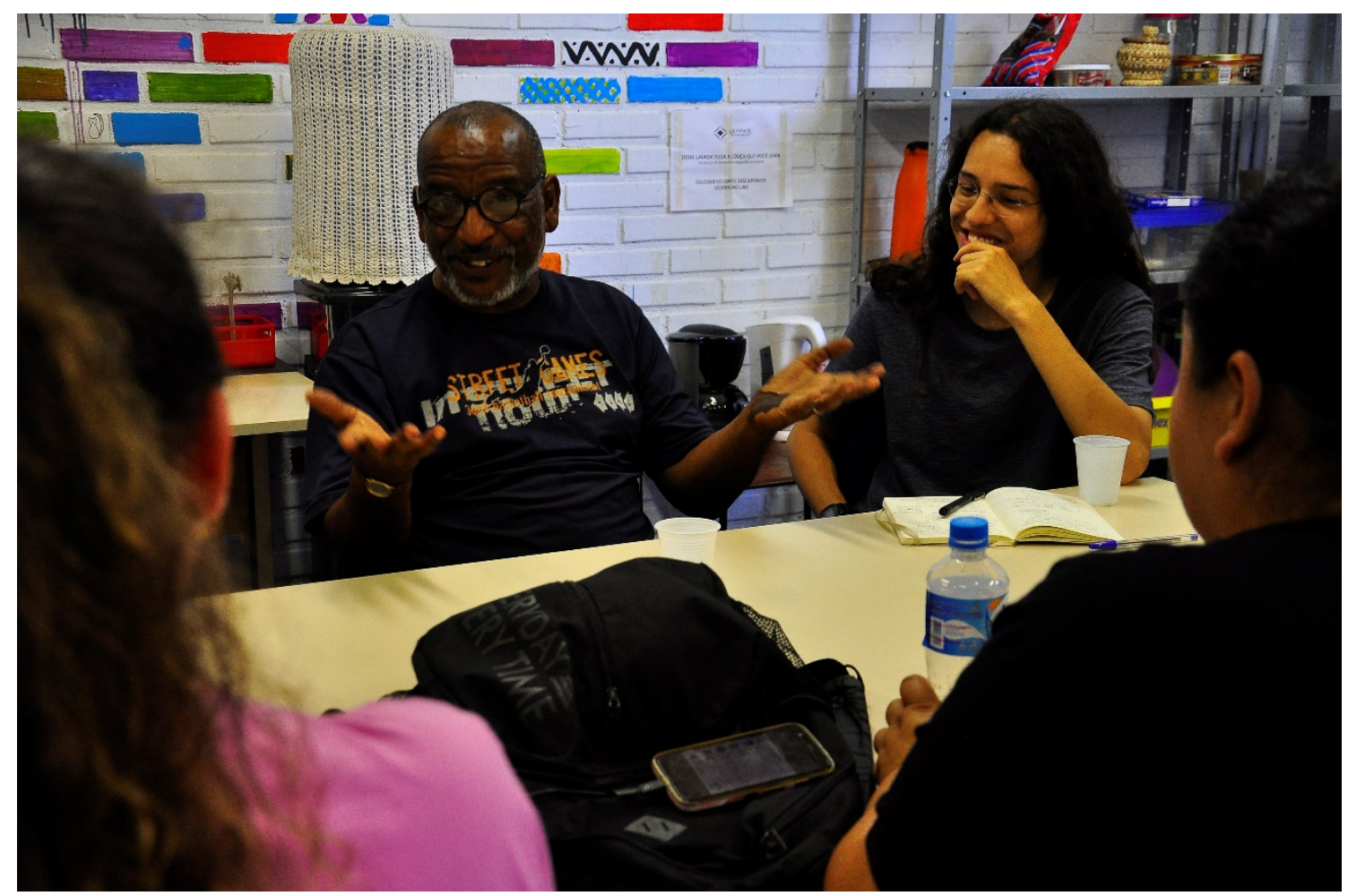

Figura 14: Orlando na reunião preparatória no LEPPAIS/UFPel.

Fonte: Fabrício Barreto

No dia seguinte, foi realizado o “Nós Nosotros”, com a temática do MEF. Um pouco antes das $18 \mathrm{~h}$ fomos recebidos na aconchegante sala da RadioCom, localizada na Galeria Antunes Maciel, centro de Pelotas. As paredes repletas de capas de discos fizeram Orlando, enquanto fã de música, identificar vários preferidos. Os microfones sobre a mesa redonda de madeira anunciavam a transmissão que estava por vir. Falar na rádio era um momento inédito para mim, assim como para os ferroviários. Após a abertura, realizada por Juliana, a professora Claudia apresentou a temática do programa:

Boa tarde, queria agradecer a acolhida do pessoal da RadioCom, como sempre. Uma alegria pra gente estar podendo se comunicar diretamente com os radiouvintes, na medida que a instituição acadêmica não nos dá essa liberdade de um contato tão próximo com a sociedade, então a oportunidade de estar aqui na rádio é uma satisfação. E hoje vamos tratar de um tema muito especial para a cidade de Pelotas, para o Brasil e que nos ocupou no ano de 2015, um pouco do ano de 2016 também, que foi a questão dos ferroviários e do patrimônio que eles contribuíram e que isso deve ser transformado num Memorial da Estação Férrea. Então, hoje aqui nós reunimos membros da equipe de pesquisa e também nosso prezados interlocutores, o senhor Orlando Chagas, que é um ferroviário aposentado e líder sindical, do sindicato dos ferroviários e o senhor Rubem, Agente aposentado. Nós primeiro passamos o microfone, para eles darem uma saudação aos ouvintes e logo após nos situamos do que se trata essa pesquisa, esse projeto e quais os desdobramentos (Claudia Turra - 16/12/2017). 


\section{A palavra foi passada para Orlando Chagas:}

Aos ouvintes a RádioCom, uma boa tarde. É um prazer estar aqui presente nessa reunião, que nós começamos a organizar ontem, e hoje estamos aqui para debater sobre o memorial da ferrovia, que nós fomos convidados pelo interlocutor... pelo Guillermo e pela professora Claudia e agradecer o convite. Vamos em frente que nós vamos tentar guardar as memórias da ferrovia, junto com universidade de Pelotas (Orlando Chagas - 16/12/2017).

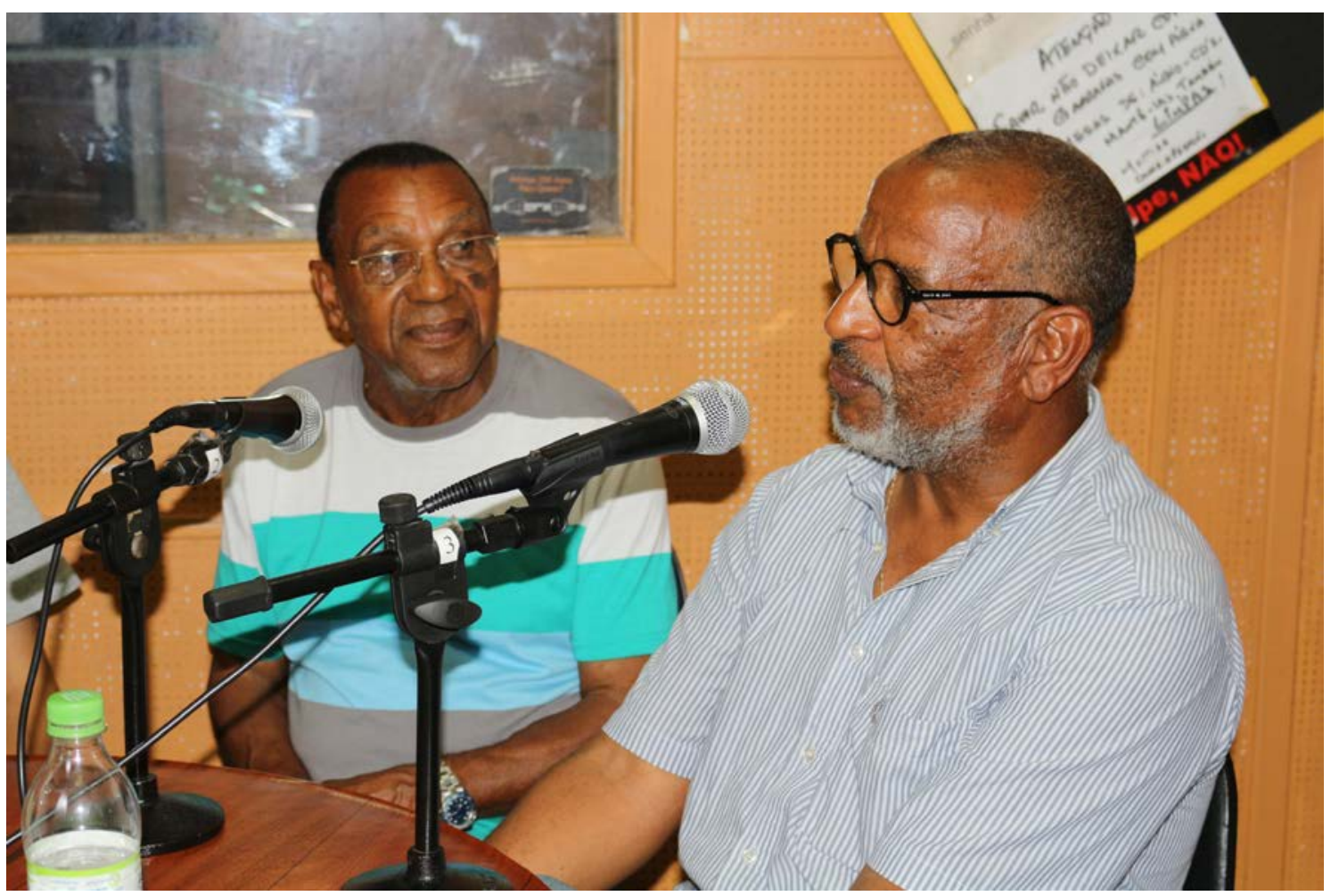

Figura 14: “Cultura transmissível”.

Fonte: Claudia Turra Magni.

Quando chegou a vez de Rubem se manifestar, ele não apenas se apresentou, mas aproveitou para "levantar um tema":

Primeiramente boa tarde, eu sou o Agente aposentado da Rede Ferroviária, e eu já queria levantar um tema, se fosse possível. O que eu tenho a informar, hoje a Rede Ferroviária tá privatizada, mas eu acho assim que, a gente ficou assim porque... A Rede Ferroviária é o transporte mais barato do país. E eu queria dizer o seguinte: o que comporta um vagão nosso, que transporta a nossa carga. $\mathrm{O}$ vagão que carrega menos carga, carrega 42 toneladas. Um vagão só! E tem outros vagões, maiores, que carregam 60 toneladas. Eu digo, porque foi privatizada e o governo optou por caminhão? Que o caminhão, para comportar toda essa carga... E o trem carrega, puxa... 60 a 80 vagões. Agora tirem uma base, o que pode dar um trem só, para puxar 60 vagões. Isso aí que eu queria trazer para toda a população pelotense. Porque um caminhão não faz todo esse transporte que um só vagão da Rede Ferroviária faz. Então era isso aí o tema que eu queria dizer (Rubem, 16/12/2017).

Iluminuras, Porto Alegre, v. 20, n. 49, p. 83-121, maio, 2019. 
Estes momentos iniciais "no ar”, configuram uma tomada de posição, de uma "arte de dizer”, que transformou o ato de fala em "apresentação de si”, e, concomitantemente, imputa uma queixa da condição precária da ferrovia. Rubem construiu um argumento que transformava a crise ferroviária em algo injustificável, ao mesmo tempo em que se afirmou enquanto voz potente e legítima em um protesto público “para toda a população Pelotense”. Após o intervalo, os ferroviários contaram como ingressaram na profissão, e Rubem encerrou sua fala assim:

O trabalho que a gente sentia, não tinha água encanada, não tinha luz. Era com vela, vela. Ou se não tinha aquele candeeiro que a gente colocava querosene naquelas meça e ali tinha uma mecha ali que acendia com fósforo e aí dava aquela fumaceira e ficava ate com os nariz assim cheio de picumã ${ }^{21}$, por causa da fumaça, a gente respirava aquilo tudo né. Então essa era a vida que a gente levava naquela época. Foi uma vida muito dolorosa. Mas, graças a deus eu tenho saúde. Tô com 80 anos, tenho saúde. Pra ver que o trabalho não faz mal a ninguém. Era isso, obrigado (Rubem, 16/12/2017).

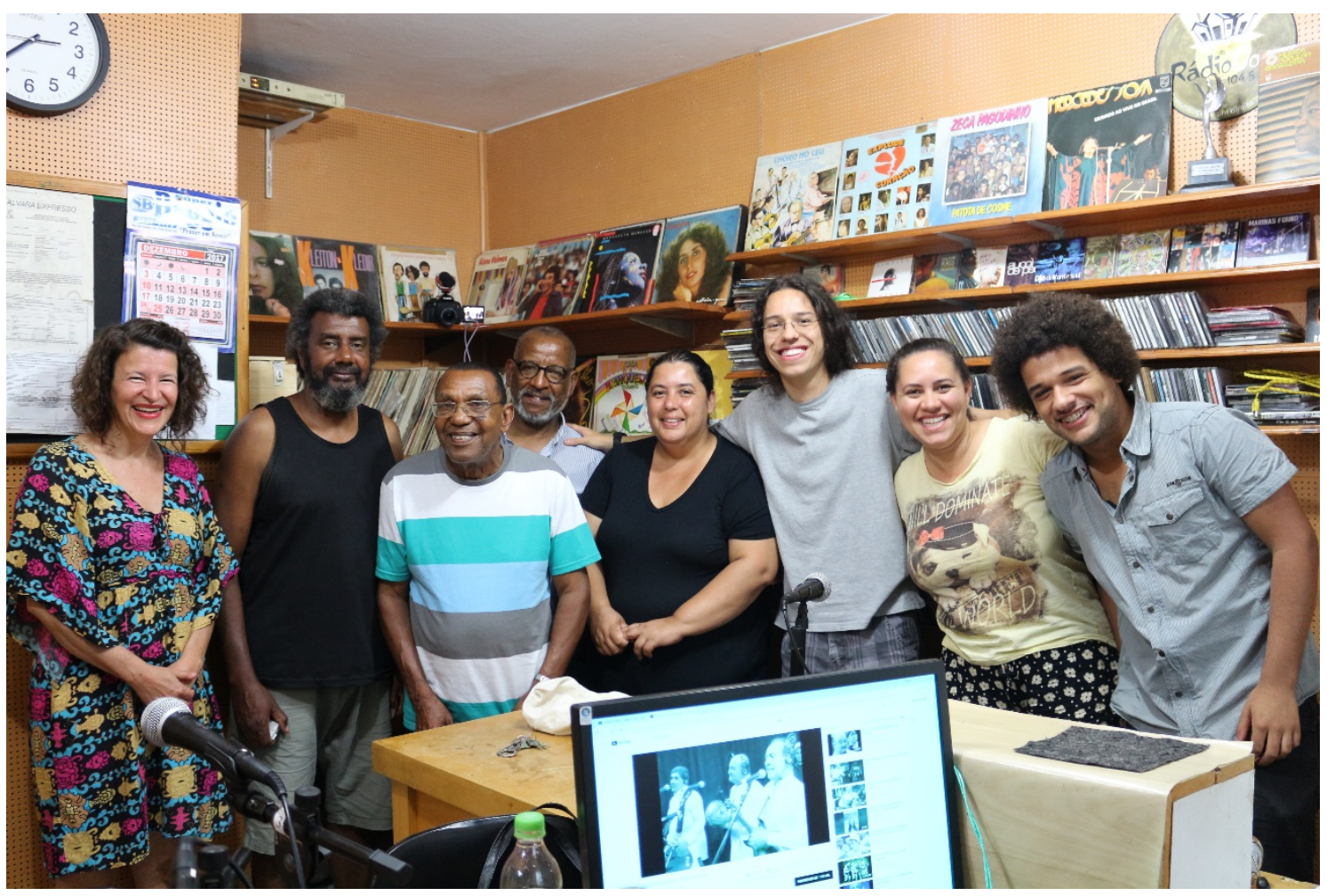

Figura 15: Da esquerda para a direita: Claudia, Glenio, Rubem, Orlando, Margot, Guillermo, Juliana e Anderson.

Fonte: Guilherme Rodrigues.

21 "Picumã! É a fuligem que se prende no interior de casa na roça onde se usa fogão a lenha” (DAWSEY, 2013, p. 129). De acordo com John Dawsey, é uma imagem do campo, que habita as cidades.

Iluminuras, Porto Alegre, v. 20, n. 49, p. 83-121, maio, 2019. 
Após este encontro na RádioCom, fui convidado por Glenio Rissio a organizar um segundo programa sobre a temática ferroviária. Isso ocorreu quando visitei sua casa, na companhia da antropóloga Andressa Pereira, para entrevistá-lo e para que ele compartilhasse conosco a seleção de músicas sobre o universo do trem e da ferrovia.

Projetamos apostar em um diálogo entre os ferroviários aposentados, dando vazão a expressão radiofônica da memória coletiva. Nos dias seguintes contatei Paulo de Carvalho, Rubem, Orlando e Neida Padilha ${ }^{22}$, ferroviária aposentada que por um compromisso não pode ir.

\section{3 "Fazendo aliados"}

O programa, realizado no dia 27 de janeiro, foi organizado por Glenio Rissio, que assumiu a mesa de som, eu e Andressa Pereira, que além de locução, fez uma pesquisa musical, do banco de dados de Glenio, selecionando músicas sobre a temática:

Essa seleção foi feita a partir do banco de dados de Glenio, com diferentes coletâneas sobre a temática do trem. Escolhi músicas de diferentes regiões do Brasil privilegiando a música nativista, por ser o gênero mais ouvido pelos ferroviários da região. Como comentou o Orlando, "música de trem é música gaúcha". O que essas músicas, de diferentes regiões do Brasil, têm em comum, é, por exemplo, a menção a temas como a ligação entre campo e cidade, a vida urbana e a vida rural, a questão da memória envolvendo o som do trem remetendo a outros tempos... Boa parte dos compositores das músicas selecionadas são de cidades que tiveram relação com a linha férrea. (Andressa Pereira - Via WhatsApp)

O programa se configurou enquanto um espaço de aprendizado coletivo. Os curtos intervalos comerciais ou chamadas para músicas, nos quais a voz da cabine é cortada, foram as oportunidades que usamos para discutir o que e quem iria falar assim que o programa voltasse ao ar. A conversa, que intitulamos "Memórias Ferroviárias na Radiocom”, integrante do “Nós Nosotros, Antropofonias e Charlas”, foi a oportunidade de conhecermos mais o personagem de Paulo Carvalho e de sua rítmica narrativa.

Boa noite, meu nome é Paulo Carvalho, estou com 81 anos. Em primeiro lugar agradecendo esta honra aqui, que para mim, que tenho origem toda ferroviária, quando me convidam para fazer parte de uma programação, me emociona muito, apesar da idade. Até porque, esses dias - eu tenho uma exposição ferroviária - um repórter perguntava por quê que eu tinha essa paixão pela ferrovia. Tem uma origem até na minha fabricação, quando meus pais me fabricaram dentro de um trem. Eles viajaram num trem quando casaram e esse trem ficou retido em Cruz Alta e dali a nove meses eu nasci. Esse é o sangue do ferroviário que eu levo e depois, várias outras coisas, mas é uma alegria grande estar aqui na presença de vocês (Paulo Carvalho, 2018).

22 Agente de Estação aposentada, uma "biografia de exceção” em um universo ferroviário predominantemente masculino. Apresento sua biografia em (Gómez, 2017; 2018a).

Iluminuras, Porto Alegre, v. 20, n. 49, p. 83-121, maio, 2019. 
Se seguiu um diálogo centrado na memória do trabalho, passando por temas como a venda de passagens e sua falsificação, a função do Chefe de Trem, do GuardaFreio e do Guarda-Chave, o carro bagageiro, as viagens clandestinas e a importância do apito do trem. Decidi reproduzir na integra o diálogo que articula o fechamento do programa, por considerá-lo uma das expressões deste projeto coletivo que envolve múltiplos atores que articulam reciprocidades, convergindo no tema da memória ferroviária:

Orlando: Voltando à pergunta que havíamos feito para o seu Paulo a respeito dos apitos do maquinista que dava sua ordem de serviço atraves do apito e, falando em apito, a Andressa, a nossa colega estudante, defendeu a tese dela sobre apito e a gente e não soube explicar para ela o que que era o apito do trem em relação aos Guarda-Freios. Então, passamos a pergunta pro seu Paulo, pra ele explicar pra nós o que significa os apitos de maquinista para os guarda freios. Porque ele exerceu essa função na ferrovia.

Paulo: Bom, o apito era um alerta. O trem, quando ia chegando uma estação - tinha há uns 500 metros uma placa que dizia qual era a estação - então ele era obrigado. O maquinista dava um apito para alertar a estação que ele tava chegando, se estivessem manobrando tinham que recolher e deixar livre, esta era uma das finalidades. Outra finalidade, muito importante, que eu vivi essa época, que eu falo do trem da serra, dessa subida de Santa Maria até Pinhal, que subia 900 metros. Quando esse trem descia, na metade da estação Pedreira, que o pai trabalhou três anos. Ele tinha um desvio de 5 lanças porque descia 900 metros. E naquele tempo era freio a vácuo, o freio a vácuo era um freio meio fraquinho, depois quando entrou o freio a ar, aí sim... Então, esse trem descia de Pinhal e às vezes acionava o freio e via que não ia segurar a composição e aí entrava em certo desespero. Então, nós tínhamos na estação Pedreira, na metade dos $18 \mathrm{~km}$, nós tínhamos uma chave que era uma chave de segurança, se ele disparava tu acionava aquela chave ele entrava e subia o morro, em vez dele descer, tinha um desvio que entrava. Então, esse trem, o sinal que ele dava, se ele saia do pinhal e ele via que não ia segurar, ele começava a acionar o apito, eu me lembro bem o apito, era assim ó “uuuiiiip, uuuiiip, uuuiip” [faz o som do apito com a boca], três apitos significa que ele vinha disparando, então, a estação de Pedreira, em que o pai foi Agente, já se preparava e virava [a chave] para ele entrar no segurança.

Orlando: "Bom, então, como esclarecido pelo seu Paulo em relação aos apitos para a Andressa, eu deixo com a palavra o Guillermo.

Guillermo: Agora, fechamos esse nosso primeiro bloco de assuntos, da memória do trabalho e agora queria propor um outro assunto, que eu acho que é bastante importante, inclusive essa proposta aqui, ela se insere nesse tema, que é da manutenção da memória. Aqui a gente tá com seu Paulo, Rubem, Orlando, que são trabalhadores já aposentados da ferrovia, mas que tão muito envolvido com justamente o que a gente tá fazendo aqui hoje né, que é relembrar a memória e quanto estamos contando em grupo a memória estamos fazendo ela durar no tempo. Então, tem uma série de iniciativas dos ferroviários aposentados, o Orlando tem acompanhado também, como delegado sindical, e eu como estudante que pesquiso com os ferroviários aposentados, formas de manter sua própria memória. Seja em exposições, seja em acervos pessoais. Quer dizer, manutenção de suas próprias fotos, de seus próprios documentos de trabalho, por exemplo, o Rubem é um grande exemplo de alguém que guarda seus próprios documentos, isso não só acaba se tornando um interesse de pesquisa, mas também articula não só a memória 
da pessoa mas de todo um grupo de trabalho. Então queria que vocês falassem um pouco desses projetos de vocês de manter essa memória. Começando com seu Paulo falando de sua exposição, porque fazer essa exposição, depois de aposentado, o que ela significa, no que ela se constitui, um pouco por onde ela já foi. Passo a palavra pro seu Paulo.”

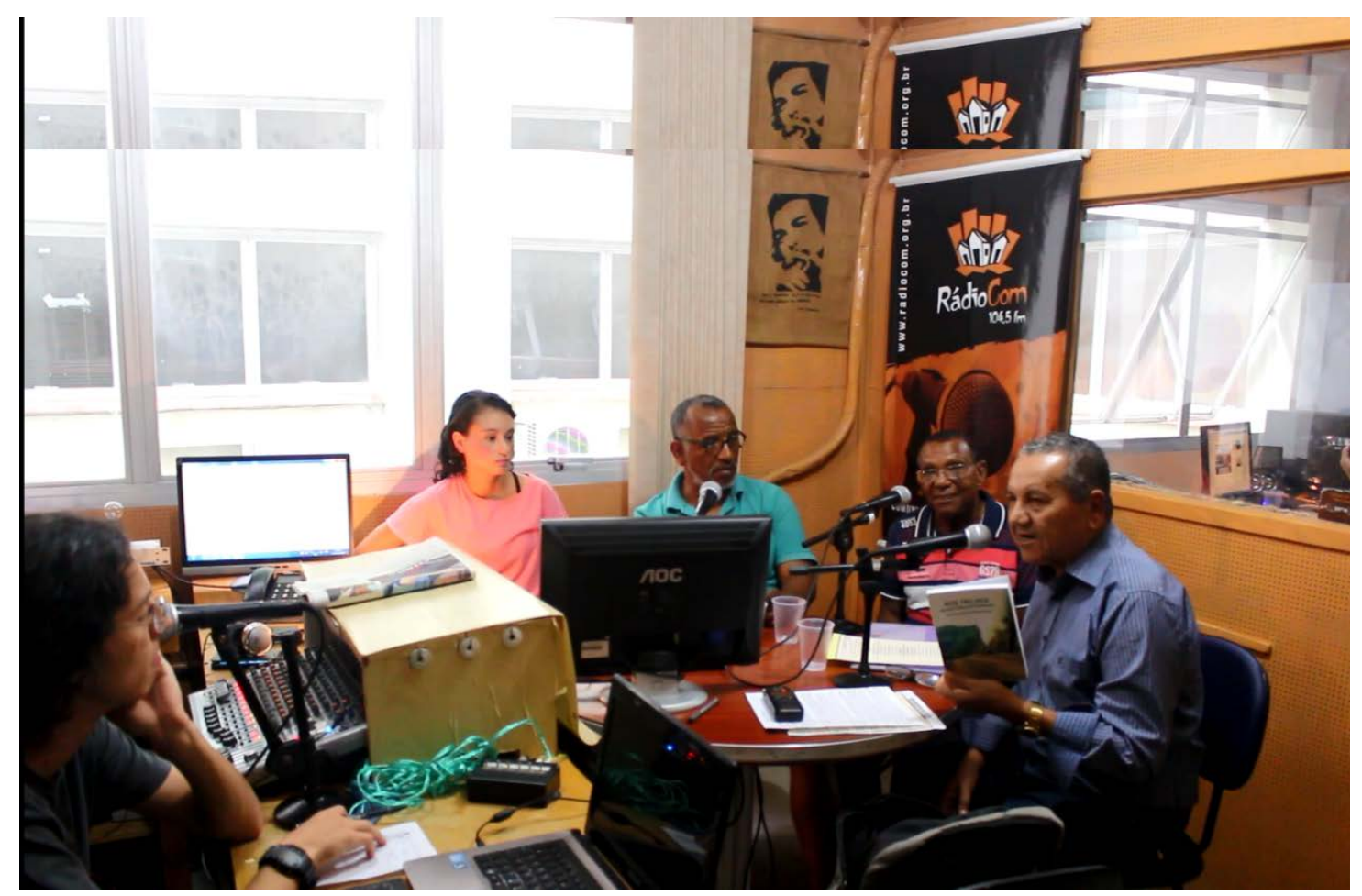

Figura 16: Memórias Ferroviárias na Radiocom.

Fonte: Glenio Rissio.

Paulo: "Em referência a memória, tu falou aí, esse negócio da exposição. Eu, logo depois que me aposentei, tenho muitos filhos no colégio, me convidavam para dar uma palestra, alguma coisa. Aí me as ideia de fazer uma exposição, mais prático né. Eu tenho 20 painéis, é bem simples porque eu não tenho recurso financeiro. Uma vez o Chico Anísio fez exposição, com os quadros aqueles, veio segurança e tudo o mais. O meu eu levo nas costas mesmo. Então, tenho 20 painéis de isopor, de $50 \mathrm{~cm}$ por 1 metro. Forrei com carpete e ali, cada painel, eu coloquei, o nome da exposição é "Nos Trilhos da Historia”. Então, cada painel tem uma história diferente. O primeiro eu começo com o início da ferrovia no mundo, chegada no Brasil, no Rio Grande do Sul, depois quadros variados. Cada quadro é diferente do outro. E tem me gratificado muito, eu tenho levado nas escolas e cada vez que eu levo o pessoal gosta muito. E me impressiona, também, o jovem, que quer saber como que era, o que que era esse trem. Então, a exposição se propõe a mostrar aquilo que era e aquilo que as pessoas não viveram, não conheceram. Principalmente hoje, me impressiona também, o pessoal gosta muito de ver, por exemplo, hoje tem trem moderno, metrô e etc. mas eu noto que até o próprio jovem ele gosta de ver como é que era esse trem antes, essa Maria Fumaça. Isso tem me gratificado muito, isso é um lado que eu levo. E outro, para manter a cultura, surgiu aí o livro, em 2011. Isso até foi o meu genro, que é professor. Ele queria que eu escrevesse um livro. Eu só comi trem, vivi trem, né tchê, a minha escola só foi escola ferroviária, meus irmãos não, meus irmão já se foram adiante. Nos éramos os mais velhso né, as nossas escolas foram as escolas chamadas 'turmeiras'. Até a ferrovia teve um lado assim preocupado. Isso é até interessante, que surgiu de um padre lá em Santa Maria, o irmão Estanislau, ele criou há uns anos atrás a campanha de 
alimentação da criança ferroviária. Então, em todo o Rio Grande do Sul, no tempo da Viação Férrea, ainda não era Rede Ferroviária. Então ele em tudo que era cidade, levando a cultura, né? Eu tenho essa é uma das que mantém a memória ferroviária. Através do livro e da minha exposição que eu procuro divulgar. Esse livro, fica bem claro, não é um livro didático, até porque eu não sou escritor, até o meu genro quando quis escrever, eu disse pra ele, mas eu não sei fazer um livro. Aí surgiu a ideia de entrevista, então eu conto alguma coisa, às vezes sai alguma bobagem... (risos) É por aí.

Orlando: Bom, baseado nesse assunto do seu Paulo, eu, o Rubinho, a gente tem que agradecer a ele que tá se misturando, como diz o ferroviário, tá se misturando no nosso meio. A gente já ganhou vários aliados. Hoje a gente já ganhou vários aliados. A gente já tinha muitas pessoas. Hoje a gente ganhou o seu Paulo e a RadioCom, também, junto com nós. Estamos empenhados em organizar o museu ferroviário. E onde a gente gostaria de fazer o museu ferroviário? É na ferrovia, na estação. Tem aquele memorial vivo, o nosso patrimônio, que é a Estação, foi restaurado, e hoje funciona lá o Cerest e o Procon e nada, nada, de ferroviário. Eu, que convivo ali diariamente, porque eu sou delegado sindical, representante aqui de Pelotas e o sindicato é ao lado da Estação, mas, está em obra e eu estou atendendo na minha casa. É uma propaganda um pouquinho do sindicato. Hoje, que que acontece, a gente tá convocando os ferroviários que todos que tiverem histórias, algo de ferroviários, que venham até nós, que não sirva para eles, vai servir para nós começar a fazer nosso memorial. E nós estamos aqui, não diariamente , mas se vocês quiserem, qualquer coisa que souberem histórias de ferroviário, porque a RádioCom está junto com nos também, é a nossa cultura transmissível, que abriu as portas para nós, ferroviários, e a gente tá engajado nisso aí. Agradecer também a professora Claudia que começou com este trabalho. Porque este trabalho começou assim, a ferrovia tem esses negócios, esses encantos. O seu Paulo tem história do casamento dele, o Rubinho tem história com o pai dele, e essas histórias tudo coincidem. Essa pesquisa começou na minha casa, da minha parte, começou com a minha filha, a minha filha foi fazer uma pesquisa sobre ferroviários e na época eu nem dei bola, eu nem dei bola mesmo. Precisou vir a Andressa, vir o Guillermo, mais a professora Claudia, pra eu descobrir esse negócio todo da ferrovia. E agora o seu Paulo apareceu, o nosso amigo Glenio, também, que ele não é ferroviário, mas é amigo de ferroviário e vive a ferrovia. Há 7 anos atrás pra ver a coincidência, ele conheceu o seu Paulo aqui, há 7 anos atrás ele já tinha entrevistado o seu Paulo, sobre a ferrovia. Pra ver como a ferrovia é tudo coincidência. Passa tudo e a ferrovia tá sempre ai, modernizada... um pouco atrasada... Só que a gente quer resgatar a ferrovia lá do início, que mantém até hoje, a tecnologia da ferrovia e nós queremos manter, como o seu Paulo tem. Na época, talvez vocês não saibam, a ferrovia funcionava com um telex, telex não...

Paulo: O nosso Facebook.

Orlando: O nosso Facebook era o telégrafo, pipipipi [imita o som com a boca]. Então umas coisas assim, o seu Paulo tem lá. O Rubinho trabalhava numa estação, tinha os telefones internos, hoje tem os celulares, mas nós já tínhamos, era caro, Rubinho falava em todas as estações, só entre eles. Era tudo através de cabos.

Rubem: Era chamado o seletivo.

Orlando, Estas histórias que a gente tem. O seu Paulo tem locomotivas, tem Maria Fumaça, tem magneto

Guillermo: Em miniatura, para deixar claro! (risos) 
Orlando: Claro, em miniatura! (risos) E nós temos. Nós, o Guillermo, a Andressa, a professora Claudia, a universidade e mais o sindicato, a gente tem os banners. Então a gente tá se unindo pra tentar fazer o memorial lá na estação. E nessa inauguração que a gente vai fazer, eu como ferroviário e sindicalista, lá em Porto Alegre tem um memorial, mas um memorial deles, na sede do sindicato, e a gente vai trazer esse memorial também na inauguração, só que esse memorial de Porto Alegre vai ficar lá. E a gente tá criando o nosso memorial. O seu Paulo, a princípio, a gente está conversando com ele, ele vai deixar o memorial dele lá, quando ele quiser ele vai lá, pega. Então esse memorial vai ser dos ferroviários, uma memória viva. Era isso que eu tinha pra falar e agradecer ao Guillermo, a Andressa, ao Glenio, a RadioCom, a presença do seu Paulo, do Rubinho. E a gente tá muito contente que acho que estamos no caminho certo, embora que estamos no Carnaval, mas pelo menos é “carnaferrovia.” Obrigado.

Esta última fala de Orlando representa, para mim, a síntese de um processo de pesquisa que durou no tempo e que se converteu em memória. Ele é transformado em narrativa bem-humorada, de luto ou mesmo de retrospectiva. Não dar bola para o trabalho de conclusão de curso da filha (Chagas, 2012), fato que Orlando tinha me contando no final de 2015, alguns dias após sua presença em minha defesa de TCC, perdura quase como um arrependimento, conforme a pesquisa sobre memória ferroviária vai tomando mais importância em sua vida.

A ferrovia é representada na narrativa como a temática que possibilita diferentes histórias coincidirem, convergirem. Assim, me aproximo de finalizar o texto indicando que as durações sempre abrem novas possibilidades. As narrativas da memória vibram com maior intensidade conforme se vai "ganhando aliados" no caminho. Os aprendizados se potencializaram, se engendraram novos projetos, amadureceram os objetivos. Todos nós, “envelhecemos juntos” (Schutz, 1979).

\section{Refletindo sobre as durações}

Orientei esse projeto intelectual de duração ferroviária mediante os ensinamentos da Etnografia da Duração. O conceito de duração foi base para as atitudes e engajamentos etnográficos, bem como modelo teórico de compreensão das atitudes do envelhecimento ferroviário frente à crise. Isso configurou uma militância compartilhada pela memória ferroviária e sua vibração e potência antropológica, mais do que sua "preservação" museal, segue dando frutos. A cronologia do artigo e "seu ponto final” não consegue captar a enxurrada de imagens que puxam umas as outras. Seguimos ativos promulgando atividades em Pelotas e região. Inauguramos exposições em parceria, somando os banners do museu de rua com os objetos e painéis de Paulo de Carvalho. Inauguramos os “encontros de gerações”, título de atividades juntos às 
escolas públicas, nas quais ferroviários octogenários dialogaram com alunos do quinto ao oitavo ano, mediante imagens projetadas no Power Point, ou guiaram os alunos em percursos pela exposição. Nessas iniciativas, nos esforçamos por tornar a memória do trabalho um saber a ser valorizado pela comunidade e fonte de aprendizado e, principalmente de trocas e parcerias.

No presente texto-recorte, optei por narrar fragmentos do processo, situações, trechos narrativos e interativos. Busquei evidenciar as possibilidades de aposentadorias resilientes, querendo explicitar as durações enquanto insubordinações à descontinuidade do tempo, que transcendem os empenhos individuais e advogam, manifestadamente, por um pertencimento coletivo à uma comunidade profissional e afetiva. Evidenciei como a crise e a duração não se dissociam, nem são antítese. A denúncia da crise é um mecanismo de perenidade dos sujeitos no tempo.

Nas redes sociais, fluem as críticas e afetividades, que recuperam uma trama de relações que foi fragmentada com a privatização da Rede Ferroviária Federal. Destaquei que o uso êmico de imagens na internet corrobora argumentos ou provoca nostalgias, sempre em âmbito coletivo. Estas ações imagéticas e cotidianas atuam para a restituição da memória coletiva, que vai se tornando colaborativa, mediante os comentários, fotos e discussões. Enfatizei uma imagem-crítica específica, que coloca a natureza em choque com a ferrovia e a agência e insubordinação do “mato” como signo da crise ferroviária.

Arregimentei relatos sobre atitudes que articulam a manutenção da memória ferroviária por meio das exposições. Neste registro, os personagens, trabalhadores aposentados se transformam em curadores, expositores, guardiões da memória. Meu intuito foi registrar uma sensibilização das pessoas que compuseram essa rede ao longo da pesquisa para as questões patrimoniais, no amplo sentido da palavra. Esta mudança de enfoque, seja êmica ou provocada por iniciativas universitárias ou do poder público, permitem uma ampla gama de atividades realizadas no período de aposentadoria e, consequentemente, a produção de novos “lugares antropológicos” aptos a serem acompanhados. Assim, a etnografia se transforma e a observação participante passa a se situar em reuniões, exposições, programas de rádio. As narrativas salientadas circunscrevem os sentidos por trás das escolhas expográficas, as falas direcionadas ao "público”, as repercussões e a interação dos sujeitos com outros atores.

Por fim, ao narrar etnograficamente esse processo de inserção quero advogar a favor de uma antropologia visual e do trabalho que seja sensível aos projetos de memória coletiva das sociedades complexas. E ao fazer isso, busco trazer ao texto as 
diferentes vozes: de minha comunidade interpretativa e acadêmica, da filiação teórica e de orientação, dos interlocutores fazendo com que vibre com mais força a indignação ferroviária perante ao estado atual das ferrovias brasileiras. 


\section{Referências}

AMORELLI, Lara Caracciolo. Cultura organizacional e relações de poder: Mapeando a Rede Ferroviária Federal S.A., em liquidação. Dissertação apresentada à escola brasileira de administração pública e de empresas para obtenção do grau de mestre Fundação Getúlio Vargas, 2003.

BACHELARD, Gaston. A dialética da duração. São Paulo: Ática, 1988.

BOLTANSKI, Luc. \& CHIAPELLO, Ève. O novo espírito do capitalismo. São Paulo: Martins Fontes, 2009.

BOLTANSKI, Luc \& THÈVENOT, Laurent . The sociology of critical capacity. European Journal of Social Theory 2(3): 359-377, 1999.

BOSI, Eclea. Memória e Sociedade: lembranças de velhos. São Paulo: Companhia das Letras, 2006.

CALLONI, Humberto. Nos trilhos da história da ferrovia: Entrevista com Paulo Nilton de Carvalho. Rio Grande: Editora da FURG, 2010.

CERTEAU, Michel de. A invenção do Cotidiano: artes de fazer (Vol 1). Rio de Janeiro: Petrópolis, 1994.

CHAGAS, Fernanda da Silva. Bailes no Ferrinho: Entre ruínas, trilhos e trilhas. 2012. 60 f. TCC (Graduação) - Curso de Ciências Sociais, Universidade Federal de Pelotas, Pelotas, 2012.

CIOCCARI, Marte. Ecos do subterrâneo: Cotidiano e memória em uma comunidade de mineiros de carvão. Rio de Janeiro: Ventura, 2015.

COGLEY, Romina. Los ancianos en el cambio familiar. Mar Del Plata a comienzos Del siglo XXI. In: Álvarez, Norberto (compilador). Cuestiones de Familia. Problemas y Debates en torno de la familia contemporánea. Mar del Plata, Universidad nacional de mar del Plata, 2007

DEBERT, Guita Grin. A reinvenção da velhice: Socialização dos processos de reprivatização do envelhecimento. São Paulo: Edusp, 2012

DELUMEAU, Jean. História do medo no ocidente: 1300-1800, uma cidade sitiada. São Paulo: Companhia das Letras, 1989

DURAND, Gilbert. A imaginação simbólica. Lisboa, Perspectiva, 1980.

ECKERT, Cornelia. Os homens da mina. Revista Ciência Hoje, v. 7, n. 41, p. 36-42 1988.

.Cornelia. Memória e trabalho: etnografia da duração de uma comunidade de mineiros do carvão (La Grand-Combe, França) Curitiba: Appris, 2012. 
FÉLIX, Jorge. O idoso e o mercado de trablho. In. ALCÂNTARA, A.; CAMARANO, A.; GIACOMIN, K. (Orgs.) Política Nacional do Idoso: Velhas e novas questões. Rio de Janeiro: Ipea, 2016

GÓMEZ, Guillermo Stefano Rosa. Cidade, Trabalho e Narrativa: Etnografia Urbana com Ferroviários Aposentados em Pelotas. Trabalho de Conclusão de Curso de Graduação em Ciências Sociais sob Orientação da Dra . Claudia Turra Magni. Pelotas/UFPel: IFISP, 2015.

Guillermo Stefano Rosa. Vida e Trabalho de uma Ferroviária: Etnografia, Memória e Gênero. Anais Eletrônicos do Fazendo Gênero 11), 2017. Disponível em: http://www.wwc2017.eventos.dype.com.br/resources/anais/1499991017_ARQUIVO_G OMEZ,G.S.R.-Vidaetrabalhodeumaferroviariaf.pdf

. Guillermo Stefano Rosa. Etnografia da Crise e da Duração Ferroviária em Pelotas: Um estudo antropológico de memória coletiva. 238 f. Dissertação (Mestrado) Curso de Antropologia Social, IFCH, Universidade Federal do Rio Grande do Sul, Porto Alegre, 2018a. Disponível em: https://lume.ufrgs.br/handle/10183/179424

. Guillermo Stefano Rosa. A locomotiva, o trem e o ferroviário: imagem e memória de uma masculinidade narrada no Sul do Brasil. Revista Latinoamericana de Antropología del Trabajo. Vol 2, No 4, 2018b. Disponível em: http://www.ceilconicet.gov.ar/ojs/index.php/lat/article/view/418

. Guillermo Stefano Rosa. Ferroviários natos e ferroviários por acaso: memórias familiares do trabalho. $42^{\circ}$ Encontro Anual da Anpocs - Caxambu (MG) SPG 18: Família, migrações e trabalho. 2018c. Diponível em:

http://www.anpocs.com/index.php/papers-40-encontro-3/spg-5/spg18-5/11483ferroviarios-natos-e-ferroviarios-por-acaso-memorias-familiares-do-trabalho/file

GÓMEZ, Guillermo Stefano Rosa \& MAGNI, Claudia Turra. Entre “Tucos” e "Bochas": A potência fabulatória dos apelidos de ferroviários aposentados na cidade de Pelotas/RS. Sociabilidades Urbanas - Revista de Antropologia e Sociologia, v.1, n. 1, p. 101-116, março de 2017. ISSN 2526-4702. Disponível em: http://www.cchla.ufpb.br/grem/sociabilidadesurbanas/SocUrbs\%20TURRAartigo.pdf

GONÇALVES, Marco Antonio. O real imaginado. Etnografia, cinema e surrealismo em Jean Rouch. Rio de Janeiro, Topbooks, 2008.

HALBWACHS, Maurice. A memória coletiva. São Paulo: Centauro, 2006.

HART, Keith. The Persuasive Power of Money. In: S. Gudeman (ed). Persuasion in Economic Life. Londres, Berghahn Books, 2007

HOLSTON, J. Cidade Modernista: uma crítica de Brasília e sua utopia. São Paulo: Companhia das Letras, 1993

INGOLD, Tim. Trazendo as coisas de volta à vida: emaranhados criativos num mundo de materiais. Horizontes Antropológicos, v.18, n.37, 2012, p.25-44. 
JEUDY, Henri-Pierre. Memórias do social. Rio de Janeiro: Forense Universitária, 1990.

LE GOFF, Jacques. Memória In. História e Memória. Campinas, SP Editora da UNICAMP, 1990.

LEFEBVRE, H. A Revolução Urbana. Belo Horizonte: UFMG, 1999

MAGNI, Claudia Turra \& GÓMEZ, Guillermo Stefano Rosa. "Vida Nos Trilhos": Desafios de um Projeto Participativo para Ensino, Pesquisa e Extensão em Antropologia Visual. Anais do $41^{\circ}$ Encontro da Anpocs. 2017. Disponível em: $<$ http://www.anpocs.com/index.php/papers-40-encontro-2/gt-30/gt14-22/10729-vidanos-trilhos-desafios-de-um-projeto-participativo-para-ensino-pesquisa-e-extensao-emantropologia-visual/file>.

NUNES, Ivanil. Douradense: A agonia de uma ferrovia. São Paulo: Annablume, 2005.

NUNES, Rojane Brum. A boca a esquina e o recanto: territórios urbanos e memória coletiva no centro de Santa Maria, RS.Santa Maria: Pallotti, 2013.

OLIVEN, Ruben George. A antropologia de grupos urbanos. Petrópolis: Vozes, 1985.

PARADELA, Celia Lima. Desestatização da rede ferroviária federal S/A. Impactos sobre os recursos humanos da administração geral. Dissertação de Mestrado em Administração Pública, Fundação Getúlio Vargas, 1998.

PEREIRA, Andressa Porto. Sonoridades do Trem na cidade de Pelotas-RS: Percepções e Significados. 2017. 112 f. Dissertação (Mestrado) - Curso de Antropologia Social, Universidade Federal de Pelotas, Pelotas, 2017.

RAPKIEWICZ, Y. S. Cidades, patrimônios e etnocolecionadores: uma etnografia das reminiscências ferroviárias no sul do Brasil. Dissertação de Mestrado, Departamento de Antropologia Social, Universidade Federal do Rio Grande do Sul, 2018. Disponível em: $<$ https://hdl.handle.net/10183/182798>. Acesso em 28/04/19

RAPKIEWICZ, Yuri S.\& ECKERT, Cornelia. Entre trilhos e temporalidades: o tempo do trabalho nas memórias dos ferroviários aposentados de Porto Alegre. In: Cornelia Eckert, Ana Luiza Carvalho da Rocha. (Org.). Etnografias do Trabalho Narrativas do Tempo. 1ed. Porto Alegre: Pallotti, p. 276-303, 2015

RICOEUR, Paul. O si e a identidade narrativa. O si-mesmo como um outro. Campinas, Papirus, 1991.

ROCHA, Ana Luiza e ECKERT, Cornelia. O antropólogo na figura do narrador. In: $O$ tempo e a cidade. Porto Alegre, UFRGS, 2005. 
ROCHA, Ana Luiza Carvalho e ECKERT, Cornelia. Etnografia da duração. Porto Alegre: Marcavisual, 2013

ROCHA, Ana Luiza Carvalho e ECKERT, Cornelia. Etnografia do trabalho, narrativas do tempo. Porto Alegre: Marcavisual, 2015a.

ROCHA, Ana Luiza Carvalho e ECKERT, Cornelia. A preeminência da imagem e do imaginário nos jogos da memória coletiva em coleções etnográficas. Brasília: ABA, 2015b.

ROUCHOU, Joelle. Memória do olfato: o cheiro de jasmim. In. VELLOSO, Mônica, ROUCHOU, Joelle \& OLVIEIRA, Cláudia. (Orgs.) Corpo: identidades, memórias e subjetividades. Rio de Janeiro: Mauad X, 2009

SCHUTZ, Alfred. In. WAGNER, Helmut R. (Org. e Introdução). Fenomenologia e relações sociais. Textos (escolhidos de Alfred Schutz). RJ, Zahar, 1979.

SEGATA, Jean. Dos cibernautas às redes. In SEGATA \& RIFIOTIS (Orgs.) Políticas etnográficas no campo da cibercultura. Brasília: ABA publicações, 2016

SENNETT, Richard. A cultura do novo capitalismo. Rio de Janeiro: Record, 2015a.

SILVA JUNIOR, Roberto. O transporte ferroviário de cargas no Brasil e na Argentina: da implantação à recente privatização. Revista de Economia Política e História Econômica, número 07, junho de 2007.

SILVEIRA, Márcio Rogério. A importância geoeconômica das estradas de ferro no Brasil. 2003. xxii, 453 f. Tese (doutorado) - Universidade Estadual Paulista, Faculdade de Ciências e Tecnologia, 2003. Disponível em: <http://hdl.handle.net/11449/101439>.

SIMMEL, G. O Dinheiro na Cultura Moderna. In: Jessé Souza e Berthold Oëlze (orgs). Simmel e a Modernidade. Brasília, Editora da Universidade de Brasília, 1998

SIMÕES, J. A. Provedores e Militantes: imagens de homens aposentados na família e na vida pública. In: Família e Envelhecimento, Clarice Peixoto (org.). Rio de Janeiro: FGV, 2004.

VELHO, Gilberto. Individualismo e Cultura: Notas para uma Antropologia da sociedade contemporânea. Rio de Janeiro: Zahar, 1981.

Recebido 23/04/2019

Aprovado 28/05/2019 